\title{
Improving dust simulations in WRF-Chem v4.1.3 coupled with the GOCART aerosol module
}

\author{
Alexander Ukhov ${ }^{1}$, Ravan Ahmadov ${ }^{2,3}$, Georg Grell ${ }^{3}$, and Georgiy Stenchikov ${ }^{1}$ \\ ${ }^{1}$ Division of Physical Sciences and Engineering, King Abdullah University of Science and Technology, Thuwal, Saudi Arabia \\ ${ }^{2}$ CIRES, University of Colorado, Boulder, CO, USA \\ ${ }^{3}$ NOAA Earth System Research Laboratory, Boulder, CO, USA
}

Correspondence: Alexander Ukhov (alexander.ukhov@kaust.edu.sa)

Received: 8 April 2020 - Discussion started: 19 May 2020

Revised: 6 December 2020 - Accepted: 11 December 2020 - Published: 25 January 2021

\begin{abstract}
In this paper, we rectify inconsistencies that emerge in the Weather Research and Forecasting model with chemistry (WRF-Chem) v3.2 code when using the Goddard Chemistry Aerosol Radiation and Transport (GOCART) aerosol module. These inconsistencies have been reported, and corrections have been implemented in WRFChem v4.1.3. Here, we use a WRF-Chem experimental setup configured over the Middle East (ME) to estimate the effects of these inconsistencies. Firstly, we show that the old version underestimates the $\mathrm{PM}_{2.5}$ diagnostic output by $7 \%$ and overestimates $\mathrm{PM}_{10}$ by $5 \%$ in comparison with the corrected one. Secondly, we demonstrate that submicron dust particles' contribution was incorrectly accounted for in the calculation of optical properties. Therefore, aerosol optical depth (AOD) in the old version was $25 \%-30 \%$ less than in the corrected one. Thirdly, we show that the gravitational settling procedure, in comparison with the corrected version, caused higher dust column loadings by $4 \%-6 \%, \mathrm{PM}_{10}$ surface concentrations by $2 \%-4 \%$, and mass of the gravitationally settled dust by $5 \%-10 \%$. The cumulative effect of the found inconsistencies led to the significantly higher dust content in the atmosphere in comparison with the corrected WRF-Chem version. Our results explain why in many WRF-Chem simulations $\mathrm{PM}_{10}$ concentrations were exaggerated. We present the methodology for calculating diagnostics we used to estimate the impacts of introduced code modifications. We share the developed Merra2BC interpolator, which allows processing Modern-Era Retrospective Analysis for Research and Applications, version 2 (MERRA-2) output for constructing initial and boundary conditions for chemical species and aerosols.
\end{abstract}

\section{Introduction}

Produced by wind erosion, mineral dust is one of the major drivers of climate over the Middle East (ME) (Osipov et al., 2015). Dust suspended in the atmosphere affects the energy budget by absorbing and scattering incoming solar radiation (Miller and Tegen, 1998) and by affecting cloud radiative properties (Forster et al., 2007). Dust can also negatively impact infrastructure and technology. For instance, reducing solar radiation reaching the Earth's surface dust decreases the output of photovoltaic systems. Moreover, dust deposition on solar panels deteriorates their efficiency (Sulaiman et al., 2014). Dust also has socioeconomic implications. Bangalath and Stenchikov (2015) showed that due to high dust loading, the tropical rain belt across the ME and north Africa strengthens and shifts northward, causing up to a $20 \%$ increase in summer precipitation over the semi-arid strip south of the Sahara, including the Sahel. Frequent dust outbreaks have a profound effect on air quality in the ME region (Banks et al., 2017; Farahat, 2016; Alghamdi et al., 2015; Lihavainen et al., 2016). Air pollution is characterized by near-surface concentrations of particulate matter (PM), which comprise both $\mathrm{PM}_{2.5}$ and $\mathrm{PM}_{10}$ (particles with diameters less than 2.5 and $10 \mu \mathrm{m}$, respectively). Dust is the major contributor to PM over the ME region (Ukhov et al., 2020a). The ME is also subjected to the inflow of dust from the nearby Sahara, which is another major dust source region (Osipov et al., 2015; Kalenderski and Stenchikov, 2016). Dust deposition fertilizes ocean surface waters and the seabed (Watson et al., 2000; Zhu et al., 1997).

Thus, given the impact of dust on climate, technology, human health, and ecosystems, an accurate description of dust 
effects in numerical models is essential. In the first place, it requires careful description of the dust cycle: from emission at the Earth's surface, to transport in the atmosphere, and, finally, to removal by deposition.

Most of the studies mentioned above were conducted within the group of Atmospheric and Climate Modeling at King Abdullah University of Science and Technology (KAUST) using the Weather Research and Forecasting model with chemistry (WRF-Chem) (Skamarock et al., 2005; Grell et al., 2005; Powers et al., 2017). WRF-Chem is a popular open-source tool that is widely used to study atmospheric chemistry, air quality, and aerosols (Jish Prakash et al., 2015; Khan et al., 2015; Kalenderski et al., 2013; Kalenderski and Stenchikov, 2016; Parajuli et al., 2019; Anisimov et al., 2017; Osipov and Stenchikov, 2018). This model has been used extensively to study aerosols and their impact on air quality (Fast et al., 2006, 2009; Ukhov et al., 2020a, b; Parajuli et al., 2020), climate (Zhao et al., 2010, 2011; Chen et al., 2014; Fast et al., 2006) and to analyze dust outbreaks (Bian et al., 2011; Chen et al., 2014; Fountoukis et al., 2016; Ma et al., 2019; LeGrand et al., 2019; Su and Fung, 2015; Eltahan et al., 2018; Bukowski and van den Heever, 2020) in the ME and north Africa (Zhang et al., 2015; Flaounas et al., 2016; Rizza et al., 2017; Karagulian et al., 2019; Rizza et al., 2018), North America (Zhao et al., 2012), India (Dipu et al., 2013; Kumar et al., 2014), and Australia (Nguyen et al., 2019). Many aforementioned studies utilized the WRF-Chem model coupled with the Goddard Chemistry Aerosol Radiation and Transport (GOCART) aerosol module (Chin et al., 2002). The GOCART module simulates major tropospheric aerosol components, including sulfate, dust, black and organic carbon, and sea salt, and includes algorithms for dust and sea salt emissions, dry deposition, and gravitational settling. The GOCART module is one of the most popular aerosol modules used in WRF-Chem (Bian et al., 2011; Dipu et al., 2013; Kumar et al., 2014; Chen et al., 2014; Su and Fung, 2015; Zhang et al., 2015; Flaounas et al., 2016; Fountoukis et al., 2016; Rizza et al., 2017; Flaounas et al., 2017; Nabavi et al., 2017; Chen et al., 2018; Rizza et al., 2018; Ma et al., 2019; LeGrand et al., 2019; Parajuli et al., 2019; Yuan et al., 2019; Ukhov et al., 2020a; Eltahan et al., 2018; Nguyen et al., 2019; Bukowski and van den Heever, 2020).

However, working with the WRF-Chem/GOCART modeling system, we found a few inconsistencies in the physical parameterizations which affected its performance. Firstly, we found that the diagnostic output of $\mathrm{PM}_{2.5}$ and $\mathrm{PM}_{10}$ was miscalculated. Secondly, the contribution of submicron dust particles was incorrectly accounted for in the Mie calculations of aerosol optical properties, and thus aerosol optical depth (AOD) was underestimated in comparison with observations. Thirdly, an inconsistency in the process of gravitational settling was leading to a violation of the dust and sea salt mass balance. The complete list of the WRF-Chem chem_opt namelist options that were affected is presented in Table 1.
All of these inconsistencies have affected WRF-Chem performance since 2 April 2010, when WRF-Chem v3.2 was released. We have reported all those issues, and they have been rectified in the WRF-Chem v4.1.3 code release. In this paper, we specifically discuss these corrections and evaluate how they have affected results. We demonstrate the methodology for calculating diagnostics that we used to estimate the impact of the introduced corrections. We also share with the community the Merra2BC interpolator (Ukhov and Stenchikov, 2020), which allows constructing initial and boundary conditions (IC\&BC) for chemical species and aerosols using the Modern-Era Retrospective Analysis for Research and Applications, version 2 (MERRA2) reanalysis (Randles et al., 2017). We believe that this discussion is in line with the open-source paradigm and will help users to better handle the code, understand physical links, and evaluate the sensitivity of the results to particular physical assumptions made in the code.

The paper is organized as follows: Sect. 2 describes the WRF-Chem model setup. In Sect. 3, a description of the inconsistencies found in the WRF-Chem code and their effects on the results is presented. Conclusions are presented in Sect. 4.

\section{WRF-Chem experimental setup}

To quantify the effects of introduced code modifications, we use our typical model setup which we previously adopted for simulating dust emissions using the WRF-Chem model coupled with the GOCART aerosol module. The WRFChem simulation domain (see Fig. 1) is centered at $28^{\circ} \mathrm{N}$, $42^{\circ} \mathrm{E}$, with a $10 \mathrm{~km} \times 10 \mathrm{~km}$ horizontal grid $(450 \times 450$ grid nodes). The vertical grid comprises 50 vertical levels with enhanced resolution closer to the ground. The model top boundary is set at $50 \mathrm{hPa}$. We use the chem_opt=300 namelist option, which corresponds to simulation using the GOCART aerosol module without ozone chemistry.

The unified Noah land surface model (sf_surface_physics $=2$ ) and the revised MM5 MoninObukhov scheme (sf_sfclay_physics=1) are chosen to represent land surface processes and surface layer physics. The Yonsei University scheme is chosen for planetary boundary layer (PBL) parameterization $\left(b l \_p b l \_p h y s i c s=1\right)$. The WRF single-moment microphysics scheme ( $m p \_$physics $=4$ ) is used for the treatment of cloud microphysics. The new Grell scheme (cu_physics=5) is used for cumulus parameterization. The Rapid Radiative Transfer Model (RRTMG) for both shortwave (ra_sw_physics=4) and longwave (ra_lw_physics=4) radiation is used for radiative transfer calculations. Only the aerosol direct radiative effect is accounted for. More details on the physical parameterizations used can be found at http://www2.mmm.ucar.edu/wrf/users/phys_references.html (last access: 20 January 2021). 
Table 1. WRF-Chem chem_opt namelist options affected by the found inconsistencies.

\begin{tabular}{llllc}
\hline & & \multicolumn{2}{c}{$\begin{array}{c}\text { Found inconsistencies in } \\
\text { calculation of }\end{array}$} \\
\cline { 3 - 5 } chem_opt & Description & PM $\begin{array}{c}\text { Optical } \\
\text { properties }\end{array}$ & $\begin{array}{c}\text { Gravitational } \\
\text { settling }\end{array}$ \\
\hline 2 & & & - & + \\
11 & MADE/SORGAM aerosols, RADM2 chemistry & - & - & + \\
41 & Same as chem_opt=2 and some aqueous reactions & - & - & + \\
42 & Same as chem_opt=2 and aqueous reactions & - & - & + \\
109 & Same as chem_opt=41 using KPP library & - & - & + \\
112 & MADE/VBS aerosols, RACM chemistry and aqueous & & & + \\
300 & GOactions using KPP library & + & + & + \\
301 & GOCART aerosols, no ozone chemistry & + & + & + \\
303 & GOCART aerosols, RACM chemistry using KPP library & + & + & + \\
401 & GOCART aerosols, RADM2 chemistry & + & + & + \\
\hline
\end{tabular}

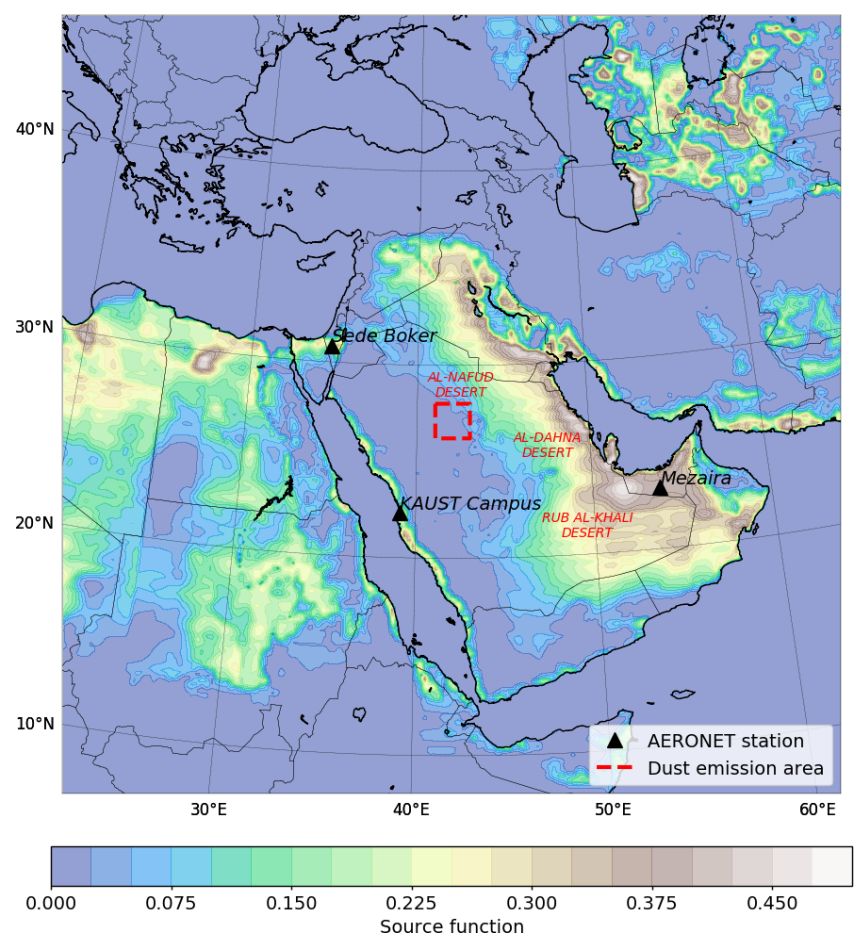

Figure 1. Simulation domain with marked locations of the AERONET sites. The red square corresponds to the dust emission area for conducting the dust mass balance check. Shaded contours correspond to source function $S$ (Ginoux et al., 2001).

Dust size distribution in the GOCART module is approximated by five dust bins; see Table 2. Dust density is assumed to be $2500 \mathrm{~kg} \mathrm{~m}^{-3}$ for the first dust bin and $2650 \mathrm{~kg} \mathrm{~m}^{-3}$ for dust bins 2-5. In WRF-Chem, there are three dust emission schemes that can be used with GOCART: the original GOCART-WRF scheme (dust_opt=1) (Bagnold, 1941; Belly, 1964; Gillette and Passi, 1988), the Air Force Weather
Table 2. Radii ranges $(\mu \mathrm{m})$ of dust and sea salt bins used in the GOCART aerosol module.

\begin{tabular}{lrrrrr}
\hline & \multicolumn{5}{c}{ Bin } \\
\cline { 2 - 6 } & 1 & 2 & 3 & 4 & 5 \\
\hline Dust & $0.1-1.0$ & $1.0-1.8$ & $1.8-3.0$ & $3.0-6.0$ & $6.0-10.0$ \\
Sea salt & $0.1-0.5$ & $0.5-1.5$ & $1.5-5.0$ & $5.0-10.0$ & - \\
\hline
\end{tabular}

Agency (AFWA) scheme (dust_opt=3) (Marticorena and Bergametti, 1995; Su and Fung, 2015; Wang et al., 2015), and the University of Cologne (UoC) scheme (dust_opt=4) (Shao, 2001, 2004; Shao et al., 2011). The detailed description of all schemes is provided in LeGrand et al. (2019).

Here, we simulate dust emissions using the original GOCART-WRF scheme (dust_opt=1) proposed in Ginoux et al. (2001). Dust emission mass flux, $F_{p}\left(\mu \mathrm{g} \mathrm{m}^{-2} \mathrm{~s}^{-1}\right)$ in each dust bin $p=1,2, \ldots, 5$ is defined by the relation

$F_{p}=\left\{\begin{array}{ll}C S s_{p} u_{10 \mathrm{~m}}^{2}\left(u_{10 \mathrm{~m}}-u_{\mathrm{t}}\right), & \text { if } u_{10 \mathrm{~m}}>u_{\mathrm{t}} \\ 0, & \text { if } u_{10 \mathrm{~m}} \leq u_{\mathrm{t}}\end{array}\right.$,

where $C\left(\mu \mathrm{g} \mathrm{s}^{2} \mathrm{~m}^{-5}\right)$ is a spatially uniform factor which controls the magnitude of dust emission flux; $S$ is the source function (Ginoux et al., 2001) (see Fig. 1) that characterizes the spatial distribution of dust emissions; $u_{10 \mathrm{~m}}$ is the horizontal wind speed at $10 \mathrm{~m} ; u_{\mathrm{t}}$ is the threshold velocity, which depends on particle size and surface wetness; $s_{p}$ is a fraction of dust emission mass flux within dust bin $p$.

Sea salt size distribution in the GOCART module is approximated by four sea salt bins (see Table 2). Sea salt density is $2200 \mathrm{~kg} \mathrm{~m}^{-3}$. Emission of sea salt is calculated according to Gong (2003). 


\subsection{Dust emission tuning}

To adjust to regional conditions, dust emission in the model is calibrated to fit observed AOD and aerosol volume size distributions (AVSDs) obtained from the AErosol RObotic NETwork (AERONET; Holben et al., 1998). AERONET AOD observations represent the total AOD with contributions from all types of aerosols. But because in the ME dust is more prevalent than all other aerosols, we focus on dust emission only. More detailed information on dust emission tuning is provided in Ukhov et al. (2020a). For this study, we choose three AERONET sites (KAUST Campus, Mezaira, and Sede Boker) located within the domain (Fig. 1). We utilize level2.0 (cloud-screened and quality-assured) AERONET AOD data. Note that from here onwards, we assume that AOD is given or calculated at $550 \mathrm{~nm}$; see Appendix C.

\subsubsection{Tuning the $C$ parameter}

To adjust dust emissions, we first tune the $C$ factor from Eq. (1), as practiced in our own studies (Kalenderski et al., 2013; Jish Prakash et al., 2015; Khan et al., 2015; Kalenderski and Stenchikov, 2016; Anisimov et al., 2017; Parajuli et al., 2019, 2020; Ukhov et al., 2020a) and in the studies of other authors (Zhao et al., 2013; Kumar et al., 2014; Flaounas et al., 2017; Rizza et al., 2017). Our test runs indicate that for the ME, $C=0.5$ achieves a good agreement between simulated and observed AOD at the KAUST Campus, Mezaira, and Sede Boker AERONET sites. Therefore, this sub-optimal value $(C=0.5)$ is retained in all subsequent runs.

\subsubsection{Tuning the $s_{p}$ fractions}

We also tune $s_{p}$ fractions from Eq. (1) to better reproduce the AVSDs provided by AERONET retrievals using the spectral deconvolution algorithm (SDA) (O'Neill et al., 2003). AERONET provides column-integrated AVSD $\mathrm{d} V / \mathrm{d} \ln r\left(\mu \mathrm{m}^{3} \mu \mathrm{m}^{-2}\right)$ on 22 logarithmically equidistant discrete points in the range of radii between 0.05 and $15 \mu \mathrm{m}$. For AVSDs, we use the AERONET v3, level-2.0 product (Dubovik and King, 2000).

In WRF-Chem, the default values of parameter $s_{p}$ from Eq. (1) are $\{0.1,0.25,0.25,0.25,0.25\}$, for the $\mathrm{DUST}_{1}$, DUST $_{2}, \ldots$, DUST $_{5}$ dust bins, respectively. They control the size distribution of emitted dust. Our test runs indicate that when we use the default $s_{p}$ values the dust volume size distributions in the atmosphere do not match those from AERONET. To achieve a better agreement between the modeled and AERONET volume size distributions, we adjust the fractions $s_{p}$ to be $\{0.15,0.1,0.25,0.4,0.1\}$. The fractions $s_{p}$ are set in the phys/module_data_gocart_dust.F file, array frac_s. We effectively increase the dust emission in the finest

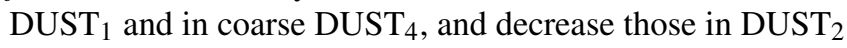

and DUST D $_{5}$ The size distribution of emitted dust is further processed in the atmosphere.

\subsection{Initial and boundary conditions for meteorological parameters, chemical species, and aerosols}

As is the case with any partial differential equation solver, WRF-Chem requires the IC\&BC for meteorological parameters and chemical species. IC\&BC for meteorological fields are derived from the ERA-Interim (Dee et al., 2011) global atmospheric reanalysis produced by the European Centre for Medium-Range Weather Forecasts (ECMWF). IC\&BC values for chemical species are required to account for initial concentrations and inflow of aerosols and chemical species. The setting of improper lateral boundary conditions for aerosols and chemistry may significantly affect the result of the simulation. The role of lateral boundary conditions increases if the domain is located close to a significant source of dust or other chemicals. Concentrations of aerosols and chemicals within the domain are especially affected by the inflow through the lateral boundaries of species with long atmospheric lifetimes.

By default, WRF-Chem uses the idealized vertical profiles of a limited number of chemical species for calculating IC\&BC. These profiles are obtained from the NOAA Aeronomy Lab Regional Oxidant Model (NALROM) model (Liu et al., 1996) simulation and are representative of the northern hemispheric midlatitude (North America) summer and clean environmental conditions. Another option in WRF-Chem is to use the output from the Model for Ozone And Related chemical Tracers, version 4 (MOZART-4) (Emmons et al., 2010), which is an offline tropospheric global chemical transport model.

The MERRA-2 reanalysis (Randles et al., 2017) provides a consistent distribution of aerosols and chemical species constrained by observations with the spatial resolution about $50 \mathrm{~km}$. MERRA-2 aerosol and chemical fields are superior compared to those used previously in WRF-Chem. To calculate the chemical IC\&BC using MERRA-2 output, we develop an interpolator (Merra2BC; Ukhov and Stenchikov, 2020), which uses gaseous and aerosol fields from MERRA2 reanalysis to construct the IC\&BC required by the WRFChem simulation. For more details regarding the Merra2BC interpolator, see Appendix A.

\section{Results}

In the discussion below, we refer to the WRF-Chem run with all inconsistencies fixed and with properly adjusted dust emission (see Sect. 2.1), with IC\&BC constructed using the developed Merra2BC interpolator (see Sect. 2.2) as ALL_OK.

To quantify the effect of each inconsistency, we perform a WRF-Chem run where all the other corrections we discuss 
Table 3. Default and updated values of the $s \_25, d \_25$, and $d \_10$ mapping coefficients used to calculate $\mathrm{PM}_{2.5}$ and $\mathrm{PM}_{10}$.

\begin{tabular}{lrl}
\hline & $\begin{array}{r}\text { Default } \\
\text { coefficients }\end{array}$ & Updated coefficients \\
\hline$s \_25$ & 0.942 & $\ln (2.5 / 1) / \ln (3 / 1)=0.834$ \\
$d \_25$ & 0.286 & $\ln (2.5 / 2) / \ln (3.6 / 2)=0.380$ \\
$d \_10$ & 0.870 & $\ln (10 / 6) / \ln (12 / 6)=0.737$ \\
\hline
\end{tabular}

here are implemented, with the exception that we focus on a given time. The relative difference $(\%)$ of a specific set of variables in this run with respect to the $A L L \_O K$ run is presented as a measure of sensitivity to the chosen correction. All WRF-Chem runs are performed for 1-12 August 2016. At the end of this section, we estimate the cumulative effect of all inconsistencies. For this purpose, we performed WRFChem simulation over the period from 1 June to 31 December of 2016.

\subsection{Calculation of $\mathbf{P M}_{2.5}$ and $P M_{10}$}

The subroutine sum_pm_gocart in module_gocart_aerosols.F calculates $\mathrm{PM}_{2.5}$ and $\mathrm{PM}_{10}$ surface concentrations using the following formulas:

$$
\begin{aligned}
\mathrm{PM}_{2.5} & =\rho \cdot\left(\operatorname{DUST}_{1}+\mathrm{DUST}_{2} \cdot d \_25+\mathrm{SEAS}_{1}\right. \\
& \left.+\mathrm{SEAS}_{2} \cdot s_{-} 25\right), \\
\mathrm{PM}_{10} & =\rho \cdot\left(\mathrm{DUST}_{1}+\mathrm{DUST}_{2}+\mathrm{DUST}_{3}\right. \\
& \left.+\mathrm{DUST}_{4} \cdot d_{-} 10+\mathrm{SEAS}_{1}+\mathrm{SEAS}_{2}+\mathrm{SEAS}_{3}\right),
\end{aligned}
$$

where $\rho$ is the dry air density $\left(\mathrm{kg} \mathrm{m}^{-3}\right), \operatorname{DUST}_{1,2,3,4}$ and $\mathrm{SEAS}_{1,2,3}$ are the mixing ratios $\left(\mu \mathrm{g} \mathrm{kg}^{-1}\right)$ of the dust in the first four bins and sea salt in the first three bins, respectively. The contribution of the dust and sea salt bins to $\mathrm{PM}_{2.5}$ and $\mathrm{PM}_{10}$ is defined by the mapping coefficients $d \_25, d \_10$ for dust and $s \_25$ for sea salt; see Eq. (2). Black and organic carbon and sulfate also contribute to PM, but over the ME region their contributions are small in comparison to dust and sea salt, and we omit them for the sake of brevity.

We suspect that the default mapping coefficients are calculated incorrectly. Therefore, we recalculated them assuming that dust and sea salt volume size distributions are functions of natural logarithm of particle radius. For example, interpolation in the logarithm space is more accurate than in the radius space, as aerosol size distributions are smoother functions of logarithm than radius. The updated values of mapping coefficients $s \_25, d \_25$, and $d \_10$ along with their default values are presented in Table 3. Effectively, the contributions in $\mathrm{PM}_{2.5}$ of sea salt $\mathrm{SEAS}_{2}$ decreases, while that of dust DUST $_{2}$ increases. The contribution of $\mathrm{DUST}_{2}$ in $\mathrm{PM}_{10}$ decreases.

The effects of using the updated mapping coefficients in place of default ones in PM calculation are shown in Fig. 2. We calculate the $\mathrm{PM}_{2.5}$ and $\mathrm{PM}_{10}$ concentrations in the low- est model layer using Eq. (2). Surface concentrations of dust and sea salt are computed using the procedure presented in Appendix E. With the default mapping coefficients, the model on average yields $7 \%$ lower $\mathrm{PM}_{2.5}$ and $5 \%$ higher $\mathrm{PM}_{10}$ concentrations over the ME.

\subsection{Calculation of aerosol optical properties}

For modeling in the ME, the treatment of optically active dust within the model is vitally important. AOD is calculated based on aerosol number density and aerosol optical properties, which depend on the aerosol size and refractive index. In WRF-Chem, a parameterized Mie theory (Ghan and Zaveri, 2007) is employed to calculate the aerosol optical properties. This parameterization is modified for the sectional representation of the aerosol size distribution by Fast et al. (2006) and Barnard et al. (2010), so the Mie subroutine requires input of dust number density or concentration in eight size intervals: $\{0.039-0.078,0.078-0.156,0.156-0.312,0.312-0.625$, $0.625-1.25,1.25-2.5,2.5-5.0$, and 5.0-10.0 $\mu \mathrm{m}$. These size intervals are identical to those used in the Model for Simulating Aerosol Interactions and Chemistry (MOSAIC) microphysical module (Zaveri et al., 2008). Therefore, we further refer to them as MOSAIC bins $\left(\operatorname{MOS}_{1,2,3,4,5,6,7,8}\right)$.

To correctly calculate the dust optical properties, we implement two corrections in the subroutine optical_prep_gocart() in module_optical_averaging.F that compute the volume-averaged refractive index needed for Mie calculations.

\subsubsection{Effect of small particles}

In WRF-Chem's GOCART aerosol module, dust particle sizes span 2 orders of magnitude, from 0.1 to $10 \mu \mathrm{m}$; see Table 2. However, we find that dust particles with radii between 0.1 and $0.46 \mu \mathrm{m}$ are incorrectly accounted for in the Mie calculations of aerosol optical properties. Their mixing ratio is mapped on coarser MOSAIC bins than is required. Since finer particles have a stronger effect on AOD per unit mass in comparison to coarser particles, the model AOD decreases. As a result, when tuning dust emission, we push the model to emit more dust into the atmosphere, in order to fit the observed AOD. We rectify this error by correcting mapping fractions of DUST 1 into MOSAIC bins; see Table 4.

Table 4 presents the mapping fractions of the GOCART dust bins (DUST $1,2,3,4$ ) to the MOSAIC bins $\left(\mathrm{MOS}_{1,2,3,4,5,6,7,8)}\right.$ before and after correction. We do not include GOCART dust bin DUST 5 in Table 4 since it is out of the MOSAIC size range and is therefore not accounted for in the mass redistribution. Also, the mass from DUST $_{4}$ is only partially accounted for. After the changes, the dust mass from the DUST $_{1}$ bin is redistributed between finer $\mathrm{MOS}_{3,4,5,6}$ bins compared to the original WRF-Chem where the entire DUST $_{1}$ mixing ratio was mapped on the coarser $\mathrm{MOS}_{5,6}$ bins. 
(a)
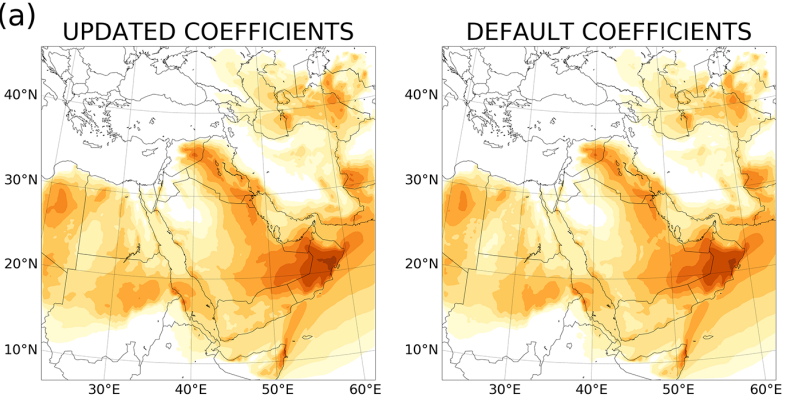

Dust+Sea salt $P M_{2.5}$ surface concentration, $\mu g / m^{3}$

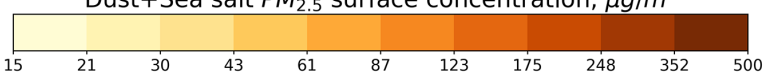

(b)
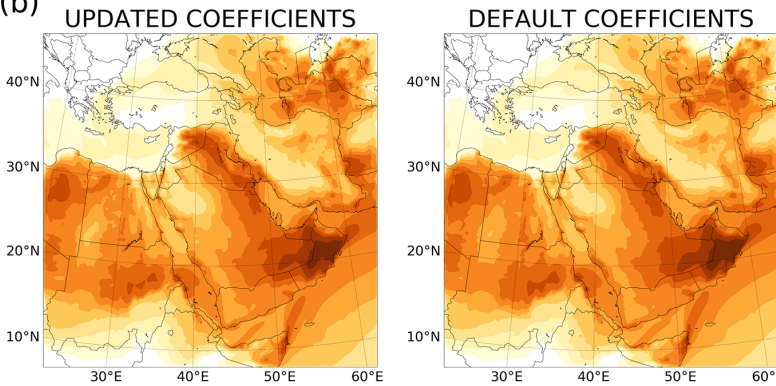

Dust+Sea salt $P M_{10}$ surface concentration, $\mu g / \mathrm{m}^{3}$

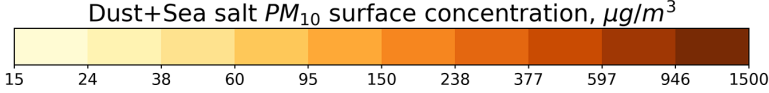

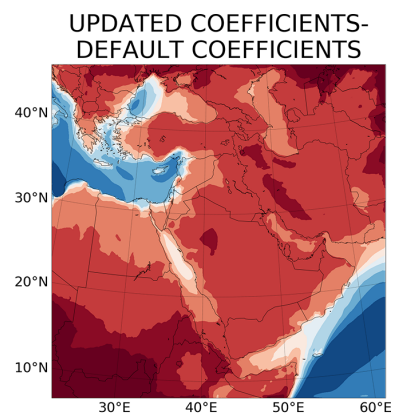

Relative difference, \%
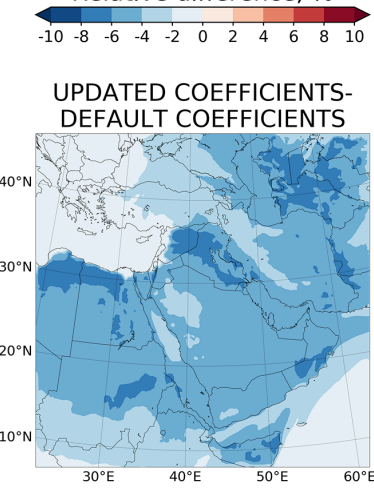

Relative difference, $\%$

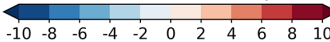

Figure 2. Average dust and sea salt $\mathrm{PM}_{2.5}$ (a) and $\mathrm{PM}_{10}$ (b) surface concentration $\left(\mu \mathrm{g} \mathrm{m}^{-3}\right)$ calculated using default and updated coefficient values and relative difference $(\%)$.

Table 4. Dust mass redistribution between GOCART and MOSAIC bins before and after inclusion of dust particles with radii $\geq 0.1 \mu \mathrm{m}$ into calculation of aerosol optical properties.

\begin{tabular}{lrrrrrrrr}
\hline Before inclusion & $\mathrm{MOS}_{1}$ & $\mathrm{MOS}_{2}$ & $\mathrm{MOS}_{3}$ & $\mathrm{MOS}_{4}$ & $\mathrm{MOS}_{5}$ & $\mathrm{MOS}_{6}$ & $\mathrm{MOS}_{7}$ & $\mathrm{MOS}_{8}$ \\
\hline DUST $_{1}$ & 0.0 & 0.0 & 0.0 & 0.0 & 0.305 & 0.695 & 0.0 & 0.0 \\
DUST $_{2}$ & 0.0 & 0.0 & 0.0 & 0.0 & 0.0 & 0.312 & 0.688 & 0.0 \\
DUST $_{3}$ & 0.0 & 0.0 & 0.0 & 0.0 & 0.0 & 0.0 & 0.583 & 0.417 \\
DUST $_{4}$ & 0.0 & 0.0 & 0.0 & 0.0 & 0.0 & 0.0 & 0.0 & 0.666 \\
\hline After inclusion & & & & & & & & \\
\hline DUST $_{1}$ & 0.0 & 0.0 & 0.062 & 0.174 & 0.347 & 0.417 & 0.0 & 0.0 \\
DUST $_{2}$ & 0.0 & 0.0 & 0.0 & 0.0 & 0.0 & 0.312 & 0.688 & 0.0 \\
DUST $_{3}$ & 0.0 & 0.0 & 0.0 & 0.0 & 0.0 & 0.0 & 0.583 & 0.417 \\
DUST $_{4}$ & 0.0 & 0.0 & 0.0 & 0.0 & 0.0 & 0.0 & 0.0 & 0.666 \\
\hline
\end{tabular}

\subsubsection{Bin concentration interpolation}

Originally, the subroutine optical_prep_gocart() redistributes dust and sea salt mass from GOCART into MOSAIC bins, using the assumption that dust size distribution is a function of particle radius. Consistent with Sect. 3.1, here we conduct interpolation assuming that dust distribution is a function of natural logarithm of radius. This modification causes changes in the mass redistribution between the GO-
CART and MOSAIC bins (see Table 5) and increases the contribution of small dust particles into the AOD. Because the dust size distribution is a smoother function of the logarithm of a radius than the radius itself, interpolation is more accurate in logarithms than in radii.

To estimate the effect of these two corrections, we develop the WRF-Chem simulation NON_LOG_O46, where only these two inconsistencies are not fixed, and compare the resulting AOD with that from the $A L L \_O K$ run. The AOD val- 
Table 5. Dust mass redistribution between GOCART and MOSAIC bins based on the assumption that bin concentration is a function of radius and on the assumption that bin concentration is a function of natural logarithm radius.

\begin{tabular}{|c|c|c|c|c|c|c|c|c|}
\hline Function of radius & $\mathrm{MOS}_{1}$ & $\mathrm{MOS}_{2}$ & $\mathrm{MOS}_{3}$ & $\mathrm{MOS}_{4}$ & $\mathrm{MOS}_{5}$ & $\mathrm{MOS}_{6}$ & $\mathrm{MOS}_{7}$ & $\mathrm{MOS}_{8}$ \\
\hline DUST $_{1}$ & 0.0 & 0.0 & 0.062 & 0.174 & 0.347 & 0.417 & 0.0 & 0.0 \\
\hline DUST $_{2}$ & 0.0 & 0.0 & 0.0 & 0.0 & 0.0 & 0.312 & 0.688 & 0.0 \\
\hline $\mathrm{DUST}_{3}$ & 0.0 & 0.0 & 0.0 & 0.0 & 0.0 & 0.0 & 0.583 & 0.417 \\
\hline $\mathrm{DUST}_{4}$ & 0.0 & 0.0 & 0.0 & 0.0 & 0.0 & 0.0 & 0.0 & 0.666 \\
\hline \multicolumn{9}{|c|}{ Function of natural logarithm radius } \\
\hline DUST $_{1}$ & 0.0 & 0.0 & 0.194 & 0.301 & 0.301 & 0.204 & 0.0 & 0.0 \\
\hline DUST $_{2}$ & 0.0 & 0.0 & 0.0 & 0.0 & 0.0 & 0.380 & 0.620 & 0.0 \\
\hline $\mathrm{DUST}_{3}$ & 0.0 & 0.0 & 0.0 & 0.0 & 0.0 & 0.0 & 0.643 & 0.357 \\
\hline $\mathrm{DUST}_{4}$ & 0.0 & 0.0 & 0.0 & 0.0 & 0.0 & 0.0 & 0.0 & 0.737 \\
\hline
\end{tabular}
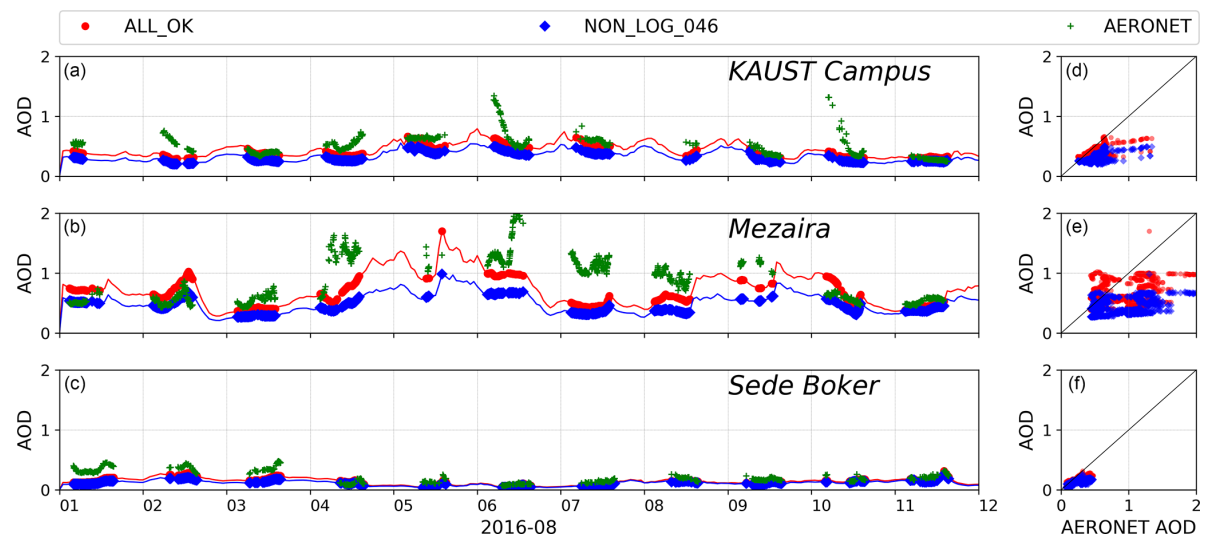

Figure 3. AOD time series (a-c) and scatter plots (d-f) from $N O N_{-} L O G \_046$ and $A L L \_O K$ runs (blue and red lines) and AERONET AOD (green markers) at KAUST Campus, Mezaira, and Sede Boker. WRF-Chem's AOD is interpolated to the times (blue diamonds and red dots) when AERONET AOD measurements were conducted.

ues are computed as described in Appendix C. As expected, the AOD increases after the corrections. Figure 3 compares the AOD obtained from the $A L L \_O K$ and $N O N \_L O G \_046$ runs with AERONET AOD at KAUST Campus, Mezaira, and Sede Boker. Because AERONET conducts measurements during daylight hours only, we interpolate WRF-Chem AOD to the AERONET measurement times.

To quantify the capability of WRF-Chem in reproducing the AERONET AOD, we calculate the Pearson correlation coefficient $R$ and mean bias (see Appendix B) of simulated AOD with respect to the AERONET AOD observations for the entire simulation period (see Table 6). The corrections improve the correlation for Mezaira and Sede Boker and cause a 2-fold reduction in the mean bias in KAUST Campus and Mezaira. The magnitude and temporal evolution of the AOD time series is well correlated in both runs (with and without corrections) with the observed AERONET AOD at all sites only when the AERONET AOD $<1$. For dusty conditions with AOD $>1$, WRF-Chem with the original GOCART scheme (dust_opt=1) struggles to capture the observations. We find the worst correlation $(R=0.42)$ and high-
Table 6. Pearson correlation coefficient $R$ and mean bias calculated for AOD time series from two runs with respect to AERONET AOD observations.

\begin{tabular}{lrr|rr|rr}
\hline & \multicolumn{2}{c|}{$\begin{array}{c}\text { KAUST } \\
\text { Campus }\end{array}$} & \multicolumn{2}{c|}{ Mezaira } & \multicolumn{2}{c}{$\begin{array}{c}\text { Sede } \\
\text { Boker }\end{array}$} \\
\cline { 2 - 7 } & $R$ & Bias & $R$ & Bias & $R$ & Bias \\
\hline ALL_OK & 0.66 & -0.10 & 0.42 & -0.19 & 0.75 & -0.07 \\
NON_LOG_046 & 0.66 & -0.20 & 0.36 & -0.38 & 0.67 & -0.11 \\
\hline
\end{tabular}

est mean bias (-0.19) with AERONET AOD at the Mezaira station, which is located in a major dust source region (see Fig. 1). We obtain higher correlations with AERONET AOD of 0.66 and 0.75 for the KAUST Campus and Sede Boker stations, respectively. Both of these stations are located outside the main dust source regions.

Figure 4 shows the averaged AOD fields obtained from the $A L L \_O K$ and NON_LOG_O46 runs, as well as their relative difference $(\%)$. We conclude that due to these two inconsistencies, averaged AOD obtained from the NON_LOG_O46 

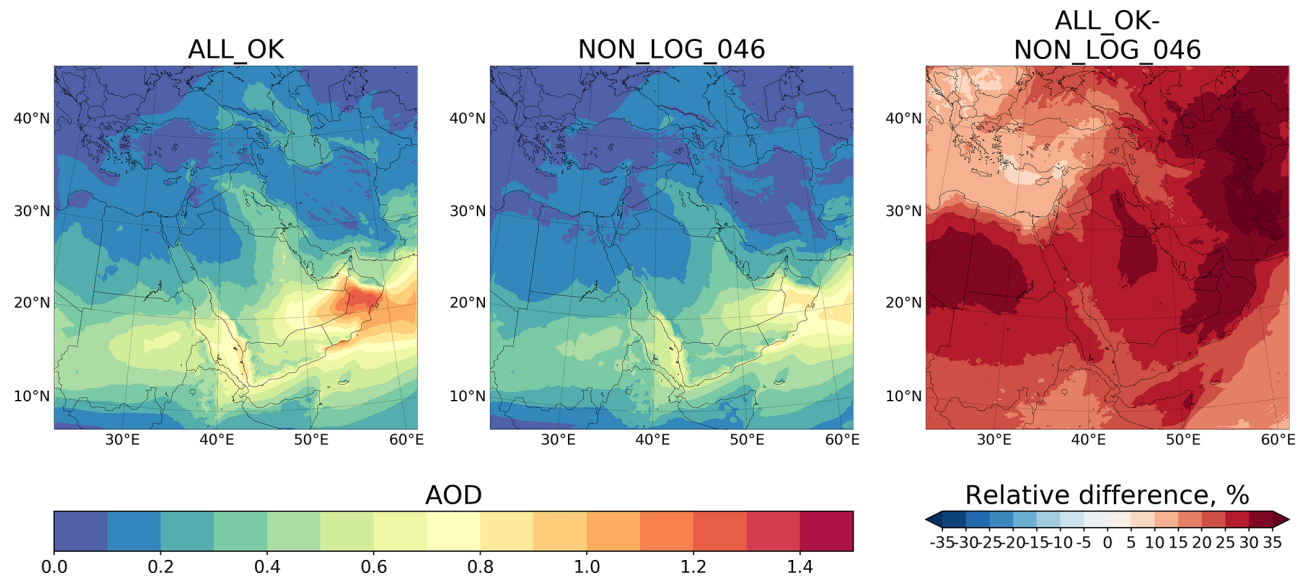

Relative difference, $\%$

$-35-30-25-20-15-10-5 \quad 0 \quad 5 \quad 101520253035$

Figure 4. Averaged AOD fields obtained from the $A L L \_O K$ and $N O N \_L O G \_O 46$ runs and their relative difference (\%).

run is lower by $25 \%-30 \%$ on average over the ME in comparison with the $A L L \_O K$ run. Over Libya, Egypt, Oman, Iran, Azerbaijan, Turkmenistan, and Pakistan, the difference is even higher, reaching $30 \%-35 \%$.

\subsection{Gravitational settling}

We find that in the original WRF-Chem code the gravitational settling of dust and sea salt is calculated incorrectly. The default finite-difference scheme (implemented in the subroutine settling() file module_gocart_settling.F) does not account for change in air density when it calculates deposition mass flux. Thus, in the course of the gravitational settling, the total mass of dust and sea salt in the atmosphere increases, violating their mass balances. We introduce the new finite-difference scheme, which allows conservation of the mass of dust and sea salt in the course of gravitational settling in the atmosphere. The new finite-difference scheme is provided below.

The change of aerosol mixing ratio due to gravitational settling at downward directed velocity $w$ is given by the following differential equation:

$\frac{\partial(\rho q)}{\partial t}=\frac{\partial(\rho q w)}{\partial z}$

where $q$ is the aerosol mass mixing ratio $\left(\mu \mathrm{gg}^{-1}\right)$ and $\rho$ is the dry air density $\left(\mathrm{kg} \mathrm{m}^{-3}\right)$. Using the first-order upwind scheme, this equation can be discretized into the following form:

$\frac{q_{k}^{n+1} \rho_{k}^{n+1}-q_{k}^{n} \rho_{k}^{n}}{\Delta t}=\frac{q_{k+1}^{n} \rho_{k+1}^{n+1} w_{k+1}^{n}-q_{k}^{n} \rho_{k}^{n+1} w_{k}^{n}}{\Delta z_{k}}$,

where $\Delta z_{k}$ is the depth of the $k$ model level, and $\Delta t$ is the model time step. Subscript $k$ denotes the model levels and superscript $n$ is the time level. Taking into account that the calculation of gravitational settling is split from the calculation of the continuity equation, we assume $\rho_{k}^{n+1} \approx \rho_{k}^{n}$ and get the following solution:

$q_{k}^{n+1}=q_{k}^{n}\left(1-\frac{\Delta t w_{k}^{n}}{\Delta z_{k}}\right)+q_{k+1}^{n} \frac{\Delta t w_{k+1}^{n}}{\Delta z_{k}} \frac{\rho_{k+1}^{n+1}}{\rho_{k}^{n+1}}$.

Equation (5) is solved for each model column from the top to the bottom.

To validate the modified finite-difference scheme, we zero dust emissions across the whole domain, except for the $200 \mathrm{~km} \times 200 \mathrm{~km}$ area located at the center of the domain; see Fig. 1. Only the first 10 simulation hours of dust emissions within this area are included. We prohibit the inflow of dust from the domain boundaries by zeroing the corresponding boundary conditions, and we zero the initial dust concentrations to simplify calculation of the dust mass balance, which we compute using the following balance relation:

Dust in the atmosphere $=$ Emitted dust

$$
\text { - (Grav. settled dust + Dry deposited dust). }
$$

The amount of dust in the atmosphere is controlled by dust emission and dust deposition. The latter comprises gravitational settling and dry deposition. For the sake of clarity, we refrain from introducing other dust removal processes, such as subgrid wet deposition (conv_tr_wetscav $=0$ ). The procedure of calculation of these diagnostics using the WRF-Chem output is provided in Appendix F.

Figure 5 demonstrates the evolution of the components of the dust mass balance (see Eq. 6) from the two runs, with and without correction of the gravitational settling procedure. For the analysis, we took only the first $40 \mathrm{~h}$ of output because, after that time the dust plume reaches the lateral boundaries of the domain. As shown in Fig. 5a, the dashed red line corresponding to the sum of deposited mass and dust mass in the atmosphere diverges from the dash-dotted purple line, which corresponds to the mass of emitted dust. This difference reaches $2.16 \%$ before the dust plume reaches the boundaries of the domain. The run using the original gravitational settling gains the dust mass represented by the blue 


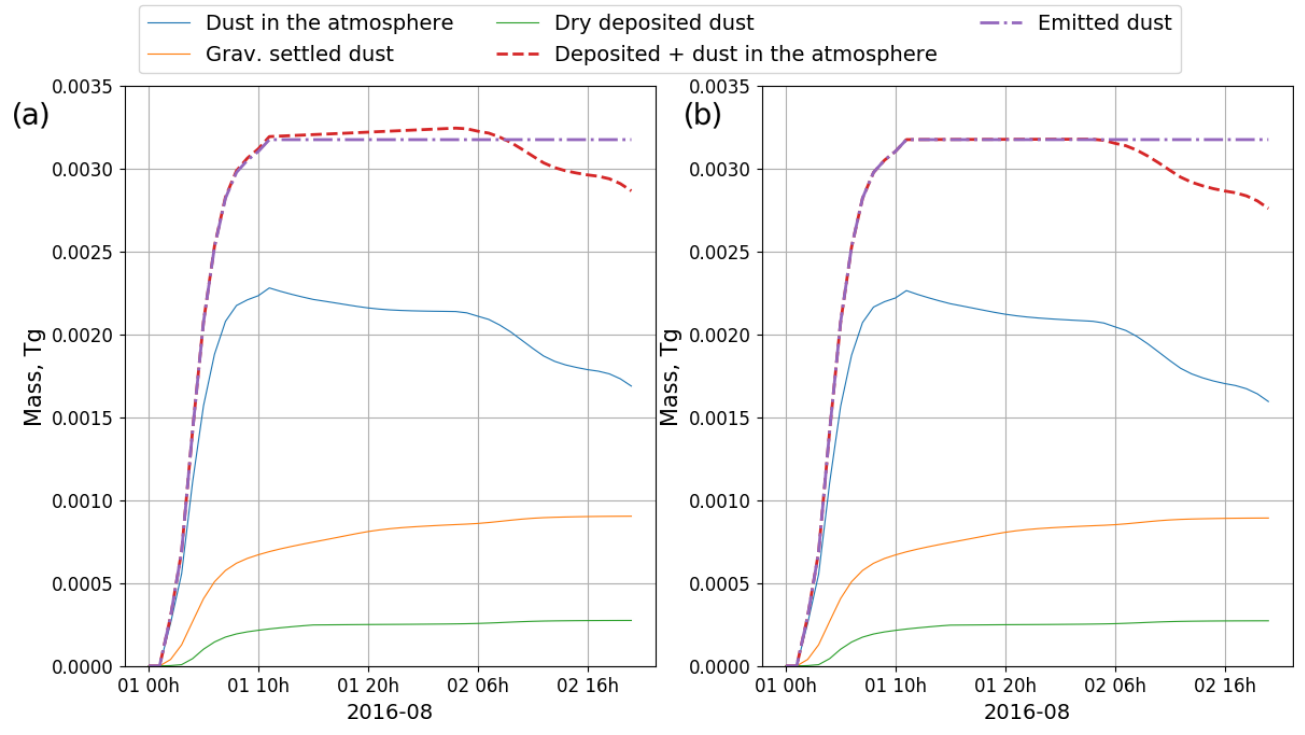

Figure 5. Dust mass balance check (a) before and (b) after correction of gravitational settling. Deposited dust is the combination of gravitationally settled dust and dry deposited dust.

line, due to the error in calculating gravitational settling, as discussed above. This is in contrast with Fig. 5b, where we see perfect agreement between the amounts of deposited dust plus dust in the atmosphere and emitted dust until the dust plume reaches the boundaries of the domain. Thus, this inconsistency in the gravitational settling subroutine is significant, as the error of $2.16 \%$ of total emitted mass accumulates within $\approx 20 \mathrm{~h}$. For a larger domain, this imbalance will be more significant. This effect is especially important in the low-latitude desert regions. Zhang et al. (2015), Dipu et al. (2013), and Huang et al. (2010) reported that in dry subtropics the boundary layer height can reach $6-7 \mathrm{~km}$, which promotes the transport of dust particles to this altitude. When dust particles are settling from higher altitudes, a larger mass imbalance is accumulated.

We estimate the effect of the gravitational settling error by comparing averaged total dust column loadings (see Fig. 6a), accumulated gravitationally settled dust (see Fig. 6b), and averaged dust and sea salt $\mathrm{PM}_{10}$ surface concentrations (see Fig. 6c) obtained in the $A L L \_O K$ and NOT_FIXED_GRAV_SETTLING runs, where the latter corresponds to the run with error in gravitational settling. We perform a comparison in terms of relative differences (\%) in the runs, with and without corrections. Dust column loadings, gravitationally settled dust, and $\mathrm{PM}_{10}$ surface concentrations are calculated according to the methodology described in Appendix Sects. D, F3, and E, respectively. According to Fig. 6a-c, we observe higher negative values of relative difference over non-dust-source regions (see Fig. 1), i.e., over Sudan, Turkey, Yemen, Eritrea, Djibouti, and Ethiopia. In contrast, the relative differences over dust source regions, which include Egypt and the eastern part of Arabian Peninsula, are close to zero. Coarse dust parti- cles have shorter lifetimes in the atmosphere because of their higher deposition velocities. Thus, coarse dust particles are mostly deposited in the dust source regions, which explains close to zero values of relative difference in this region. Fine dust particles have longer atmospheric lifetime and thus can be transported over longer distances. The discrepancies in the descriptions of the life cycle of fine dust explain larger relative errors in non-dust regions, as mentioned above.

Thus, we can conclude that in the NOT_FIXED_GRAV_SETTLING run, the total dust column loading is higher by $4 \%-6 \%$ over the ME in comparison with the $A L L \_O K$ run. The computed total amount of dust in the atmosphere (see Appendix F4) was 6.41 and $6.72 \mathrm{Tg}$ for the ALL_OK and NOT_FIXED_GRAV_SETTLING runs, respectively. Hence, the amount of dust in the atmosphere is around $4.8 \%$ higher. The total amount of gravitationally settled dust is $5 \%-10 \%$ higher on average in NOT_FIXED_GRAV_SETTLING run. The biggest difference $(15 \%-25 \%)$ is observed in Sudan, Yemen, Eritrea, Djibouti, Ethiopia, and Turkey. The computed total amount of gravitationally settled dust (see Appendix F3) was 11 and $11.55 \mathrm{Tg}$ for ALL_OK and NOT_FIXED_GRAV_SETTLING runs, respectively. Hence, the amount of gravitationally settled dust is around 5\% higher in the NOT_FIXED_GRAV_SETTLING run. Dust and sea salt $\mathrm{PM}_{10}$ surface concentrations (see Eq. 2 and Appendix E) are higher by $2 \%-4 \%$ on average over the ME in comparison with the $A L L \_O K$ run. We observe even bigger differences (6\%-10\%) over Eritrea, Djibouti, Ethiopia, and Turkey. 
(a)
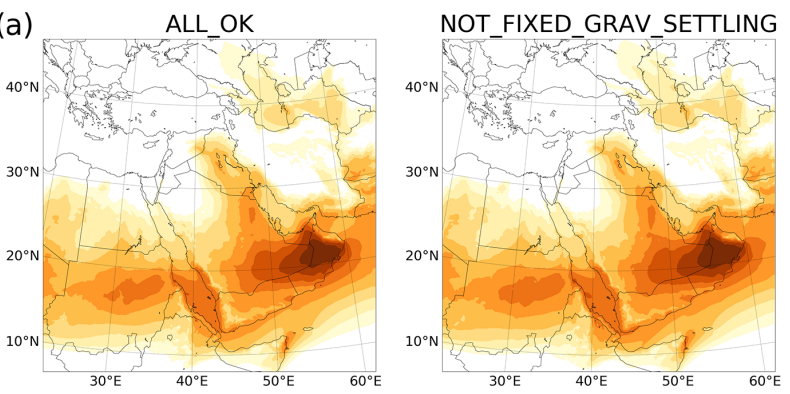

Total dust column loading, $\mathrm{g} / \mathrm{m}^{2}$

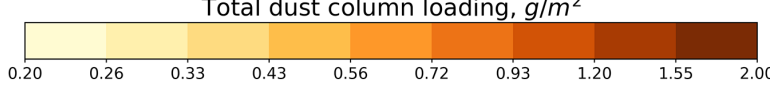

(b)
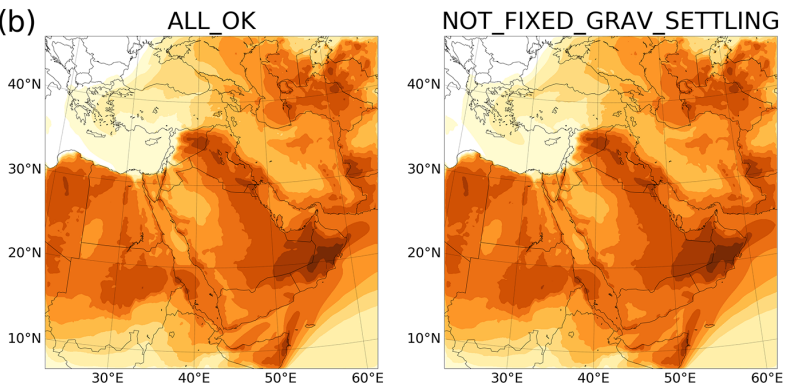

Gravitationally settled dust, $\mathrm{g} / \mathrm{m}^{2}$

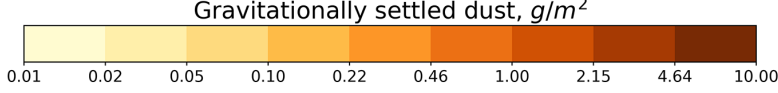

(c)
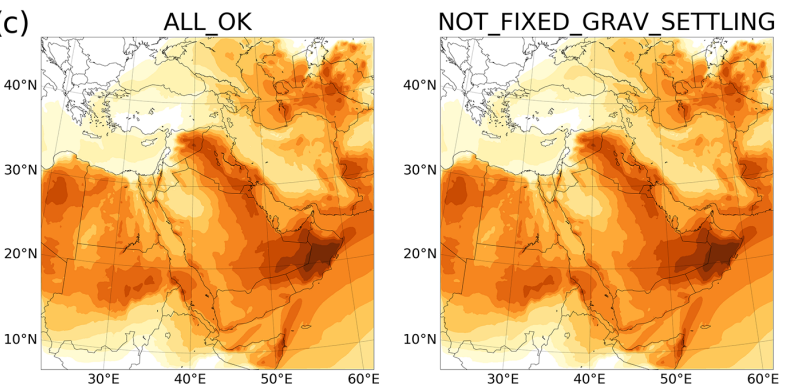

Dust+Sea salt $P M_{10}$ surface concentration, $\mu g / \mathrm{m}^{3}$

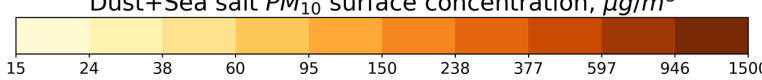

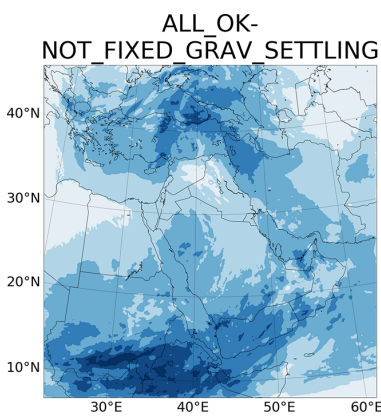

Relative difference, \%

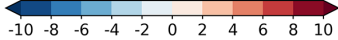

ALL_OK-

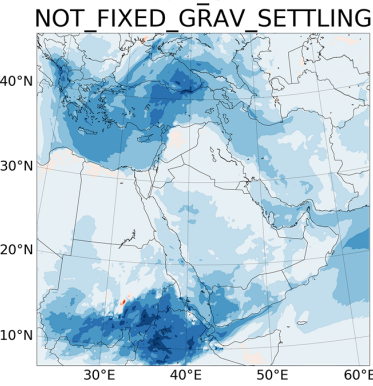

Relative difference, \%

-30-25-20-15-10-50 051015202530 ALL OK-

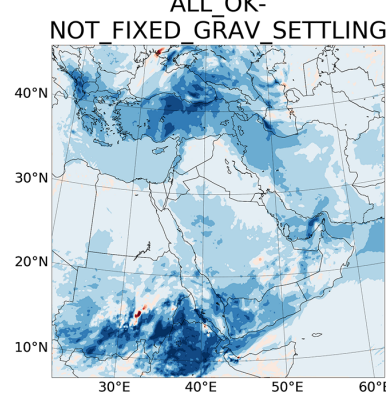

Relative difference, $\%$

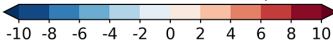

Figure 6. Comparison of $A L L \_O K$ and NOT_FIXED_GRAV_SETTLING runs. (a) Averaged total dust column loadings ( $\mathrm{g} \mathrm{m}^{-2}$ ) and relative difference (\%). (b) Gravitationally settled dust $\left(\mathrm{g} \mathrm{m}^{-2}\right)$ and relative difference (\%). (c) Averaged dust and sea salt $\mathrm{PM}_{10}$ surface concentrations $\left(\mu \mathrm{g} \mathrm{m}^{-3}\right)$ and relative difference $(\%)$.

\subsection{Case study}

In the previous sections, we separately quantified the effect of each inconsistency in the WRF-Chem code and explained the associated physical links using short-term runs. In this section, we conduct a 7-month case study to demonstrate the cumulative effect of all inconsistencies. We ran two WRFChem simulations from 1 June to 31 December 2016, using the experimental setup described in Sect. 2. We refer to the WRF-Chem run, where all inconsistencies are intact, as $A L L \_O L D$. We compare it with $A L L \_O K$ run in which all inconsistencies are corrected. The simulation period is chosen to take advantage of $\mathrm{PM}_{10}$ surface concentrations measurements conducted by the Saudi Authority for Industrial Cities and Technology Zones (MODON) in Riyadh, Jeddah, and Dammam (megacities of Saudi Arabia). More details on these measurements are provided in Ukhov et al. (2020a).

To adjust dust emissions in $A L L \_O L D$ run, we tuned the $C$ factor from Eq. (1). Our test runs indicated that $C=0.8$ provides the best agreement between simulated and observed AOD. For the ALL_OK run, we used $C=0.5$ as before. Comparison of daily averaged AOD time series obtained 

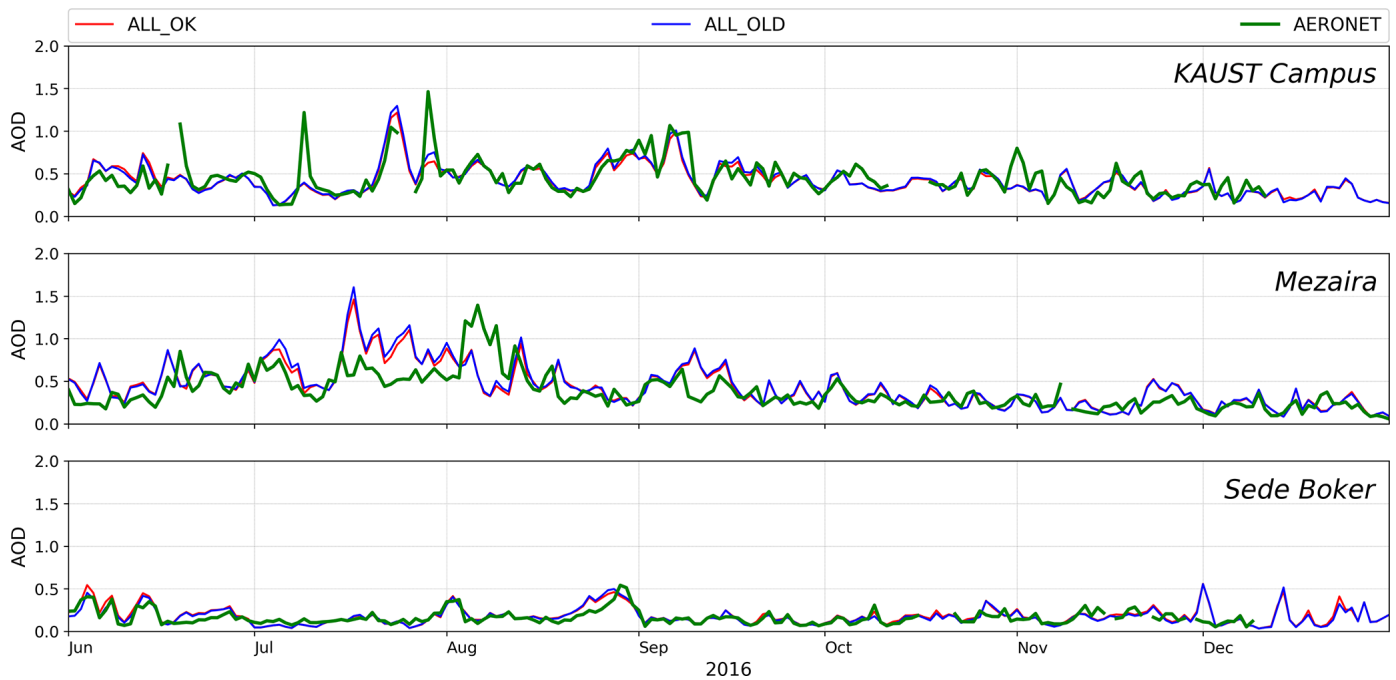

Figure 7. Daily averaged AOD time series from the $A L L \_O K$ and $A L L \_O L D$ runs (red and blue lines) and AERONET AOD (green line) at KAUST Campus, Mezaira, and Sede Boker.

from the $A L L \_O K$ and $A L L \_O L D$ runs with the AERONET AODs at KAUST Campus, Mezaira, and Sede Boker is presented in Fig. 7. AODs from both experiments are in good agreement with the AERONET AOD. The Pearson correlation coefficients and mean biases (see Appendix B) with respect to AERONET AOD are in the ranges of 0.62-0.75 and $-0.03-0.07$, respectively, for all AERONET sites. Thus, in the ALL_OLD run, the incorrect mapping of dust particles with radii between 0.1 and $0.46 \mu \mathrm{m}$ causes stronger dust emissions in comparison with $A L L \_O K$ run.

The stronger dust emissions lead to increased dust surface concentrations and increased dust content in the atmosphere. Figure 8 shows comparison of the daily averaged $\mathrm{PM}_{10}$ surface concentrations obtained from the $A L L \_O K$ and $A L L \_O L D$ runs and from MODON observations in Riyadh, Jeddah, and Dammam. Modeled $\mathrm{PM}_{10}$ concentrations were computed using Eq. (2). $\mathrm{PM}_{10}$ constituents were sampled at the exact MODON stations locations. We used "default" and "updated" mapping coefficients $\left(s \_25, d \_25\right.$, and $d_{-} 10$; see Table 3 ) for the evaluation of $\mathrm{PM}_{10}$ concentrations from the ALL_OLD and ALL_OK runs, respectively. Average MODON $\mathrm{PM}_{10}$ concentrations are 136, 206, and $229\left(\mu \mathrm{g} \mathrm{m}^{-3}\right)$ for Jeddah, Riyadh, and Dammam, respectively. $\mathrm{PM}_{10}$ concentration time series from the $A L L \_O K$ run demonstrate better agreement with the MODON observations in comparison with the $\mathrm{PM}_{10}$ time series from the $A L L \_O L D$ run. In particular, mean biases with respect to MODON observations for $A L L \_O K$ and $A L L_{-} O L D$ runs are 2,23 , and 77 , and 72,182 , and $275\left(\mu \mathrm{g} \mathrm{m}^{-3}\right)$ for Jeddah, Riyadh, and Dammam, respectively; see Fig. 8. Thus, the $\mathrm{PM}_{10}$ concentration bias in $A L L_{-} O K$ is lower by $50 \%-85 \%$ in comparison with the $A L L \_O L D$ run.

Figure 9 demonstrates the averaged over the summer (June, July, August) of 2016 total dust column loadings $\left(\mathrm{g} \mathrm{m}^{-2}\right)$ and their relative differences $(\%)$ obtained from the $A L L \_O K$ and $A L L \_O L D$ runs. In some locations, dust content in the atmosphere from the $A L L \_O L D$ run is higher by $80 \%$ in comparison with the $A L L \_O K$ run. The total mass of dust in the atmosphere in the $A L L \_O K$ run yields $6.68 \mathrm{Tg}$ in comparison with $10.92 \mathrm{Tg}$ in the $A L L \_O L D$ run, so the difference exceeds $60 \%$.

\subsection{Effect of initial and boundary conditions}

We specifically conduct a sensitivity simulation to examine the impact of boundary conditions on $\mathrm{PM}_{10}$ surface concentration over the ME. In this simulation, boundary conditions are constructed using the developed Merra2BC interpolator (Ukhov and Stenchikov, 2020) (see Appendix A), and we zero the initial concentrations of dust and sea salt. The emissions of dust and sea salt within the domain are turned off (dust_opt $=0$, seas_opt $=0$ ). In this instance, $\mathrm{PM}_{10}$ concentrations are entirely determined by the inflow from the lateral boundaries. The averaged $\mathrm{PM}_{10}$ surface concentrations are presented in Fig. 10. $\mathrm{PM}_{10}$ concentrations are calculated using Eq. (2). Figure 10 shows the inflow of $\mathrm{PM}_{10}$ from Africa, central Asia, and the Indian Ocean. Dust is the major contributor to the $\mathrm{PM}_{10}$ transported from Africa and central Asia, whereas sea salt contributes to $\mathrm{PM}_{10}$ transported over the Indian Ocean.

\section{Conclusions}

In this paper, we discuss the inconsistencies found in the WRF-Chem v3.2 model coupled with the GOCART aerosol module. All of these inconsistencies are rectified in the WRFChem v4.1.3 code release. Here, we demonstrate the effect of the code rectification on WRF-Chem model performance. 

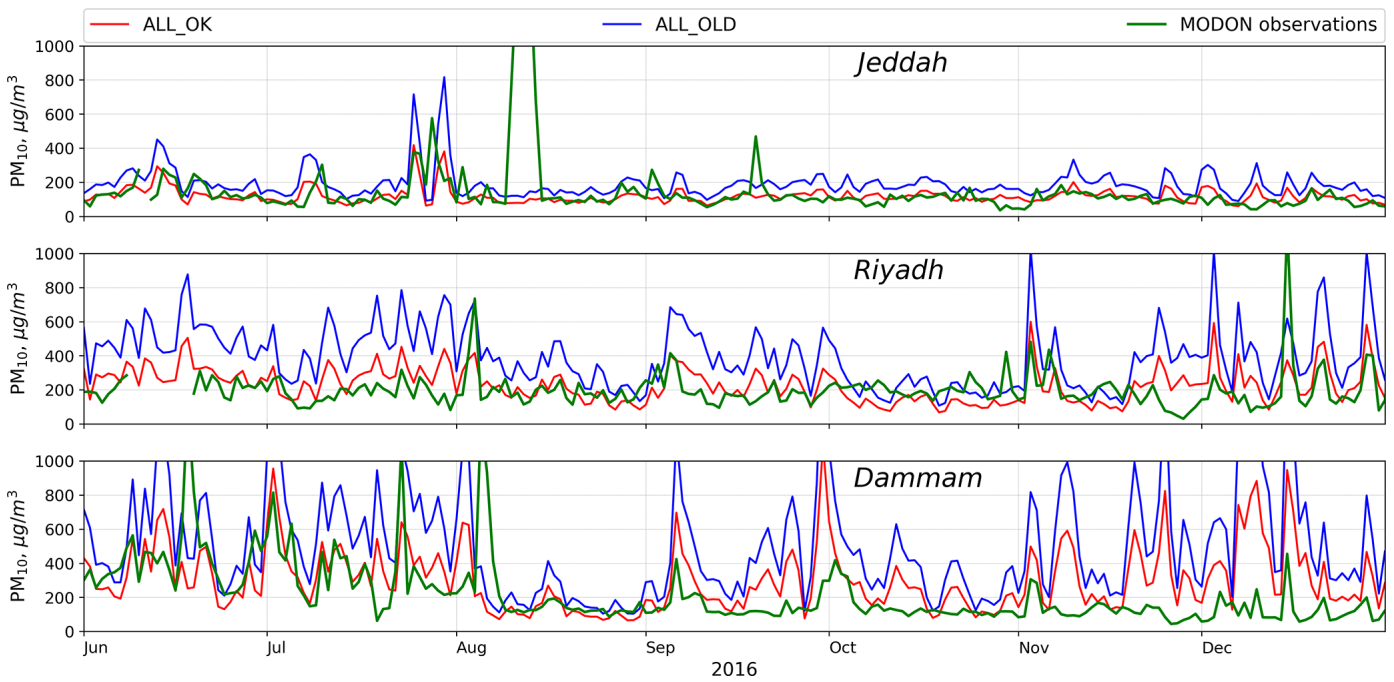

Figure 8. Daily averaged $\mathrm{PM}_{10}$ surface concentrations $\left(\mu \mathrm{g} \mathrm{m}^{-3}\right)$ from the $A L L \_O K$ and $A L L \_O L D$ runs (red and blue lines) and from MODON observations (green line) at Jeddah, Riyadh, and Dammam.
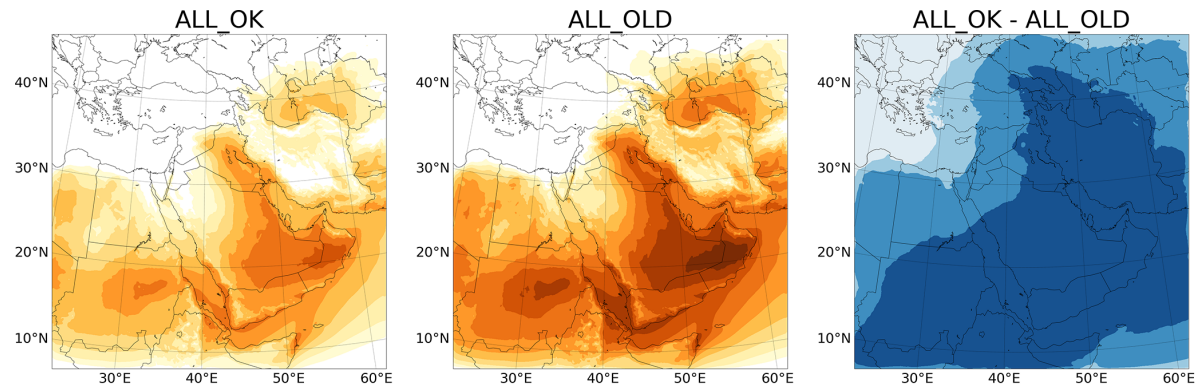

Total dust column loading, $\mathrm{g} / \mathrm{m}^{2}$
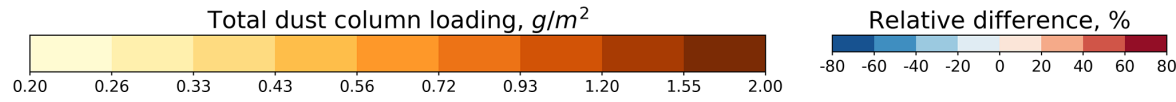

Figure 9. Averaged over the summer (June, July, August) of 2016 total dust column loadings $\left(\mathrm{g} \mathrm{m}^{-2}\right.$ ) from the $A L L \_O K$ and $A L L \_O L D$ runs and relative difference $(\%)$.

We also demonstrate the methodology we employ to calculate diagnostics, which we then use to estimate the effects of the changes made. To make these assessments, we configure the WRF-Chem domain over the ME and run it with $10 \mathrm{~km}$ grid resolution. The runs discussed in this paper were performed over the period of 1-12 August 2016. The effect of each inconsistency was estimated using specifically designed WRF-Chem runs where only one model inconsistency was activated.

We found that in WRF-Chem v3.2 coupled with GOCART, the inconsistency in diagnostics of PM surface concentration caused a $7 \%$ decrease in $\mathrm{PM}_{2.5}$ and a $5 \%$ increase in $\mathrm{PM}_{10}$ surface concentrations. Due to drawback in mapping of dust particles with radii between 0.1 and $0.46 \mu \mathrm{m}$ from GOCART to MOSAIC bins for Mie calculations of aerosol optical properties, the modeled AOD was decreased by $25 \%-30 \%$ in comparison with the corrected WRF-Chem version. This led to higher dust emissions and surface PM concentrations, because the WRF-Chem model is tuned to fit the simulated AOD to AERONET observations. This explains the inconsistencies found in Kumar et al. (2014), Eltahan et al. (2018), and Flaounas et al. (2017). Flaounas et al. (2017) noted that the model simulates realistic AODs when dust emissions are exaggerated, which in turn results in exaggerated dust surface concentrations. Conversely, realistic reproduction of dust concentration yields AODs that are smaller than in observations. Because of the error in calculating gravitational settling, dust column loadings increased by $4 \%-6 \%$ and the mass of gravitationally settled dust increased by $5 \%-10 \%$ in comparison with the corrected WRFChem version. The contribution of dust and sea salt into $\mathrm{PM}_{10}$ surface concentration was also higher by $2 \%-4 \%$ on average over the ME.

The cumulative effect of all inconsistencies was estimated in the 7-month case study conducted for 1 June-31 December 2016, when both AERONET AODs and $\mathrm{PM}_{10}$ surface 


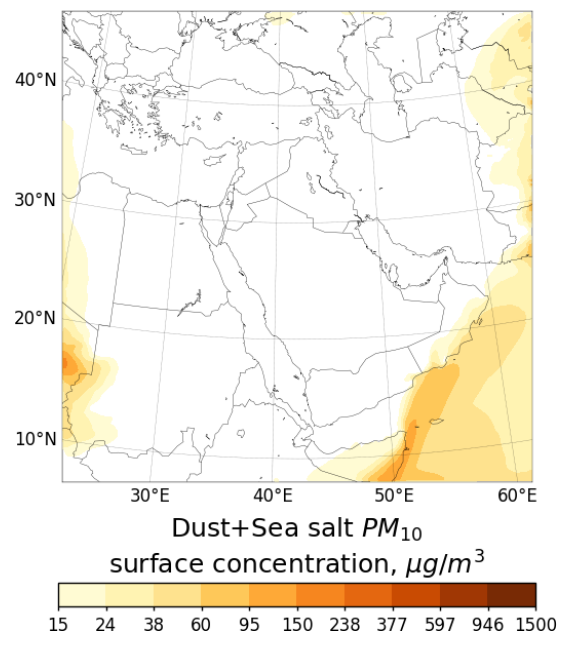

Figure 10. Effect of transboundary transport. Averaged dust and sea salt $\mathrm{PM}_{10}$ surface concentrations $\left(\mu \mathrm{g} \mathrm{m}^{-3}\right)$ are obtained from the WRF-Chem simulation without emission of sea salt and dust.

observations were available. The comparison of runs with and without proposed changes shows that the run without corrections yields higher dust loadings and total dust mass in the atmosphere by $80 \%$ and $60 \%$, respectively. This 7 month case study shows that the cumulative response to all code modifications applied simultaneously is stronger than the sum of their partial contributions. For instance, AOD underestimation causes higher dust emissions, which causes higher dust surface concentrations and increased production of dust in the atmosphere due to the error in gravitational settling. As a consequence, $\mathrm{PM}_{10}$ surface concentration further increases. Finally, an already high $\mathrm{PM}_{10}$ surface concentration becomes even higher due to the incorrect calculation of $\mathrm{PM}_{10}$. Thus, the proposed improvements help to explain the considerable bias towards higher $\mathrm{PM}_{10}$ concentrations found in Ma et al. (2019), Flaounas et al. (2017), Su and Fung (2015), Nabavi et al. (2017), Rizza et al. (2017), and Eltahan et al. (2018).
In the course of improving the simulation of natural and anthropogenic aerosols and chemicals, we developed the capability to use MERRA-2 reanalysis for constructing WRF-Chem initial and boundary conditions for chemical species and aerosols. The interpolation utility Merra2BC was coded for this purpose. Boundary conditions constructed using MERRA-2 reanalysis more realistically account for the transboundary transport of aerosols. Merra2BC is made available to the community.

We believe the detailed quantification of the effects of the recent WRF-Chem code improvements are in line with opensource principles. The results of this work aim at better understanding of the model sensitivities to physical parameterizations. This work will add a greater understanding of model performance and will be especially helpful for those who use the WRF-Chem model coupled with the GOCART aerosol module to carry out dust simulations over regions where dust plays an important role. 


\section{Appendix A: Merra2BC interpolator}

The Merra2BC interpolator (Ukhov and Stenchikov, 2020) (available online at https://github.com/saneku/Merra2BC) creates initial and boundary conditions based on MERRA-2 reanalysis (Randles et al., 2017) for a WRF-Chem simulation by interpolating chemical species mixing ratios defined on the MERRA-2 grid to WRF-Chem grid. For the initial conditions, interpolated values are written to each node of the WRF-Chem grid. For the boundary conditions, only boundary nodes are affected.

Merra2BC is written in Python. The utility requires additional modules that need to be installed in the Python environment: NetCDF4 (netcdf4, https://github.com/Unidata/ netcdf4-python, last access: 20 January 2021) interface to work with NetCDF files and SciPy's (scipy, https://github. com/scipy/scipy, last access: 20 January 2021) interpolation package.

The full MERRA-2 reanalysis data set including aerosol and gaseous collections is publicly available online (https://disc.gsfc.nasa.gov/daac-bin/FTPSubset2.pl, last access: 20 January 2021). Depending on the requirements, all or one of the following aerosol and gaseous collections need to be downloaded: inst3_3d_aer_Nv - gaseous and aerosol mass mixing ratios, $\left(\mathrm{kg} \mathrm{kg}^{-1}\right)$ and inst3_3d_chm_Nv - carbon monoxide and ozone mass mixing ratios, $\left(\mathrm{kg} \mathrm{kg}^{-1}\right)$. Besides downloaded mass mixing ratios, pressure thickness $D E L P$ and surface pressure $P S$ fields also need to be downloaded. Spatial coverage of the MERRA-2 files should include the area of the simulation domain. The time span of the downloaded files should match the start and duration of the simulation. More information regarding MERRA-2 files' specification is provided in Bosilovich et al. (2016).

\section{A1 Reconstruction of the pressure in MERRA-2 and in WRF-Chem}

Atmospheric pressure is used as a vertical coordinate. Latitude and longitude serve as the horizontal coordinates.

The MERRA-2 vertical grid has 72 model layers which are on a terrain-following hybrid $\sigma-p$ coordinate. The pressure at the model top is a fixed constant, $P_{\mathrm{TOP}}=0.01 \mathrm{hPa}$. Pressure at the model edges is computed by summing the DELP starting at $P_{\text {TOP. }}$. A representative pressure for the layer can then be obtained by averaging pressure values on adjacent edges. Indexing for the vertical coordinate is from top to bottom; i.e., the first layer is the top layer of the atmosphere ( $\left.P_{\mathrm{TOP}}\right)$, while the 72 nd layer is adjacent to the Earth's surface.

In WRF-Chem, the pressure field is not given in wrfinput_d01 and $w r f b d y \_d 01$ files. Hence, the pressure field must be restored using surface pressure $P_{\mathrm{SFC}}$ taken from met_em_..* files created by metgrid.exe during the preprocessing stage. Pressure at the top of the model wrf_p_top and $\eta$ values on half levels (znu) are taken from the wrfin-

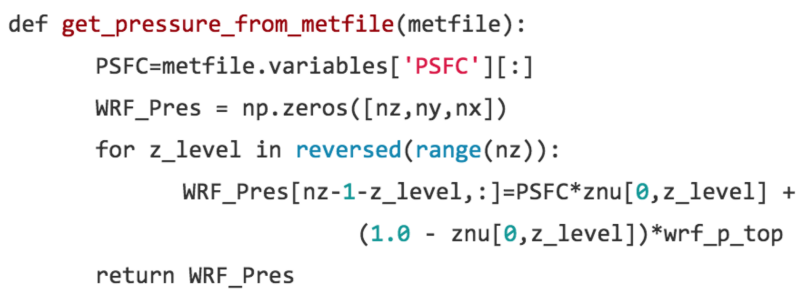

Figure A1. A Python script, which reconstructs the pressure using the $m e t \_e m_{-} . . *$ files. nx, ny, and nz indicate the number of grid nodes in WRF-Chem domain.

put_d01 file. The procedure of reconstructing the pressure from $m e t \_e m_{-} . . . *$ files using the Python code is demonstrated in Fig. A1.

\section{A2 Mapping chemical species between MERRA-2 and WRF-Chem}

Merra2BC file config.py contains multiplication factors to convert MERRA-2 mass mixing ratios of gases given in $\mathrm{kg} \mathrm{kg}^{-1}$ into ppmv. Aerosols are converted from $\mathrm{kg} \mathrm{kg}^{-1}$ to $\mu \mathrm{g} \mathrm{kg}^{-1}$. When using the GOCART aerosol module in WRF-Chem simulation, all MERRA-2 aerosols and gases are matched with those from WRF-Chem. We simply multiply by a factor of $10^{9}$ to convert MERRA-2 aerosol mixing ratios given in $\mathrm{kg} \mathrm{kg}^{-1}$ into $\mu \mathrm{g} \mathrm{kg}^{-1}$. In the case of gases, we need to multiply MERRA-2 mass mixing ratios by a ratio of molar masses $M_{\text {air }} / M_{\text {gas }}$ multiplied by $10^{6}$ to convert $\mathrm{kg} \mathrm{kg}^{-1}$ into ppmv, where $M_{\text {gas }}$ and $M_{\text {air }}$ are molar masses $\left(\mathrm{g} \mathrm{mol}^{-1}\right)$ of the required gas and air $\left(28.97 \mathrm{~g} \mathrm{~mol}^{-1}\right)$, respectively. If another aerosol module is chosen in WRF-Chem, then different multiplication factors should be used.

\section{A3 Interpolation procedure}

A brief description of the interpolation procedure applied to the initial conditions is presented in Fig. A2.

For boundary conditions, the procedure is similar, except that additional updates of domain boundary tendencies are required and interpolation is performed for each step, where boundary conditions are applied.

\section{A4 Typical workflow}

Here are the steps describing how to work with the Merra2BC interpolator:

1. Run real.exe, which will produce initial wrfinput_d01 and boundary conditions $w r f b d y \_d 01$ files required by the WRF-Chem simulation.

2. Download required MERRA-2 files from https://disc. gsfc.nasa.gov/daac-bin/FTPSubset2.pl;

3. Download Merra2BC from https://github.com/saneku/ Merra2BC. 


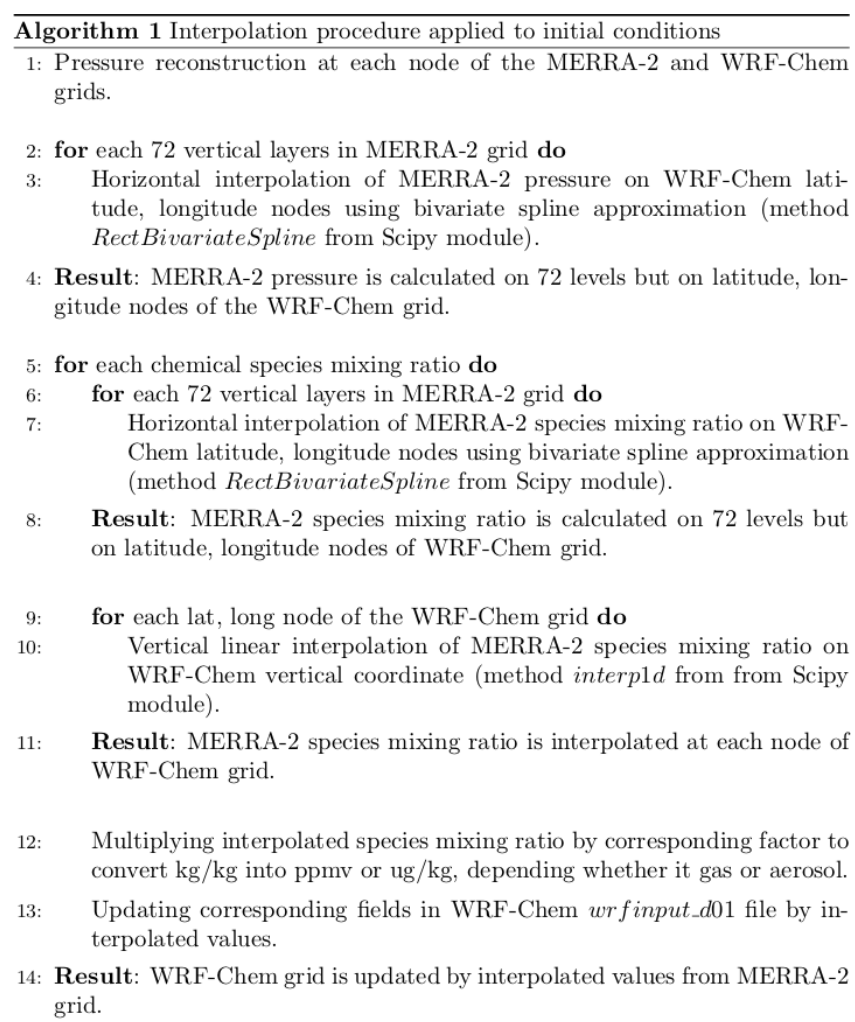

Figure A2. Interpolation procedure applied to initial conditions.

4. Edit the config.py file which contains

a. mapping of chemical species and aerosols between MERRA-2 and WRF-Chem;

b. paths to wrfinput_d01, wrfbdy_d01, and met_em_...*files;

c. a path to the downloaded MERRA-2 files.

5. real.exe sets default boundary and initial conditions for some chemical species. Merra2BC adds interpolated values to the existing values, which may cause incorrect concentration values. To avoid this, run "python zero_fileds.py", which will zero the required fields.

6. Run "python main.py", which will do the interpolation. As a result, files wrfinput_d01 and $w r f b d y \_d 01$ will be updated by the interpolated from MERRA-2 values.

7. Modify the WRF-Chem namelist.input file at section \&chem: set have_bcs_chem $=$.true. to activate updated boundary conditions and, if needed, chem_in_opt $=1$ to activate updated initial conditions.

8. Run wrf.exe.

\section{Appendix B: Statistics}

The following statistical parameters were used to quantify the level of agreement between estimations and observations.

For the Pearson correlation coefficient $(R)$,

$$
R=\frac{\sum_{i=1}^{N}\left(F_{i}-\bar{F}\right)\left(O_{i}-\bar{O}\right)}{\sqrt{\sum_{i=1}^{N}\left(F_{i}-\bar{F}\right)^{2} \sum_{i=1}^{N}\left(O_{i}-\bar{O}\right)^{2}}} .
$$

For the mean bias (bias),

bias $=\frac{1}{N} \sum_{i=1}^{N}\left(F_{i}-O_{i}\right)$

where $F_{i}$ is the estimated value, $O_{i}$ is the observed value, $\bar{F}=\frac{1}{N} \sum_{i=1}^{N} F_{i}$ and $\bar{O}=\frac{1}{N} \sum_{i=1}^{N} O_{i}$ their averages, and $N$ is the number of data.

\section{Appendix C: AOD calculations}

WRF-Chem does not calculate AOD at $550 \mathrm{~nm}$ (only at $300,400,600$, and $1000 \mathrm{~nm}$ for variables TAUAER1, TAUAER2, TAUAER3, and TAUAER4, respectively), but instead it outputs the extinction coefficient at $550 \mathrm{~nm}$ (variable EXTCOF55). The AOD at $550 \mathrm{~nm}\left(\mathrm{AOD}_{550}\right)$ for the $(i, j)$ vertical column can be calculated by summing throughout the vertical column of product of multiplication of the EXTCOF 55 by the $\Delta z$ :

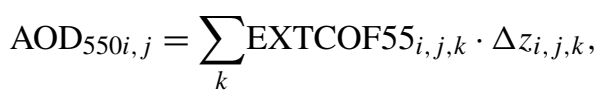

where $\Delta z_{i, j, k}$ is the depth (m) of the $(i, j, k)$ cell, which can be computed using the formula:

$$
\begin{aligned}
\Delta z_{i, j, k} & =\left(\mathrm{PH}_{i, j, k}+\mathrm{PHB}_{i, j, k}\right) / g \\
& -\left(\mathrm{PH}_{i, j, k-1}+\mathrm{PHB}_{i, j, k-1}\right) / g,
\end{aligned}
$$

where $\mathrm{PH}$ is the geopotential and PHB is the perturbed geopotential, and $g=9.81 \mathrm{~m} \mathrm{~s}^{2}$ is the gravitational acceleration. Variables PH and PHB are taken from the WRF-Chem output.

To facilitate comparison with the model output, the $550 \mathrm{~nm}$ AOD is calculated using the following relation:

$$
\frac{\tau_{\lambda}}{\tau_{\lambda_{0}}}=\left(\frac{\lambda}{\lambda_{0}}\right)^{-\alpha}
$$

where $\alpha$ is the Ångström exponent for the 440-675 nm wavelength range provided by AERONET, $\tau_{\lambda}$ is the optical thickness at wavelength $\lambda$, and $\tau_{\lambda_{0}}$ is the optical thickness at the reference wavelength $\lambda_{0}$. 


\section{Appendix D: Column loadings}

WRF-Chem stores dust column loadings $\left(\mu \mathrm{g} \mathrm{m}^{-2}\right.$ ) using variables DUSTLOAD_1,2,3,4,5. Column loadings for the $(i, j)$ vertical column of other aerosols or chemical species can be computed by vertically summing throughout the vertical column of product of multiplication of the mass mixing ratio $q\left(\mu \mathrm{g} \mathrm{kg}^{-1}\right)$ by the cell depth $\Delta z$ (m) (see Eq. C2) and dry air density $\left(\mathrm{kg} \mathrm{m}^{-3}\right)$. WRF outputs variable $A L T$, which is inverse dry air density $\left(\mathrm{m}^{3} \mathrm{~kg}^{-1}\right)$ :

Column loading ${ }_{i, j}=\sum_{k} q_{i, j, k} \cdot \Delta z_{i, j, k} \cdot 1 / \operatorname{ALT}_{i, j, k}$.

WRF-Chem outputs gases concentrations expressed in ppmv. Conversion from ppmv to the mass mixing ratio can be calculated using the following formula:

Mass mixing ratio $=\mathrm{ppmv} \cdot 10^{-6} \cdot M_{\mathrm{gas}} / M_{\mathrm{air}}$,

where $M_{\mathrm{gas}}$ and $M_{\text {air }}$ are molar masses $\left(\mathrm{g} \mathrm{mol}^{-1}\right)$ of the required gas and air $\left(28.97 \mathrm{~g} \mathrm{~mol}^{-1}\right)$, respectively.

\section{Appendix E: Surface concentrations}

Surface concentration $\left(\mu \mathrm{g} \mathrm{m}^{-3}\right)$ of an aerosol at $(i, j)$ vertical column can be computed by multiplication of the mass mixing ratio $\left(\mu \mathrm{g} \mathrm{kg}^{-1}\right)$ at the first model level $\left(q_{1}\right)$ by the corresponding dry air density $\left(\mathrm{kg} \mathrm{m}^{-3}\right)$ at the first model level $\left(1 / \mathrm{ALT}_{1}\right)$ :

Surface concentration ${ }_{i, j}=q_{i, j, 1} \cdot 1 / \mathrm{ALT}_{i, j, 1}$.

To obtain gas surface concentration $\left(\mu \mathrm{g} \mathrm{m}^{-3}\right)$, ppmv needs to be converted to the mass mixing ratio; see Eq. (D2).

\section{Appendix F: Dust mass balance}

In WRF-Chem's GOCART aerosol module, dust emissions along with three types of removal processes (dry deposition, gravitational settling, and wet scavenging) are implemented. Here, for the sake of clarity, we refrain from consideration of wet scavenging. To calculate the dust mass balance, assuming there is no flow of dust through the domain boundaries, we need to calculate the amount of dust emitted from the domain area, the amount of dust that was deposited by gravitational settling and dry deposition, and the amount of dust in the atmosphere. By default, WRF-Chem stores instantaneous values of dust emission and deposition fluxes. We modified the WRF-Chem code to accumulate the dust emission and deposition fluxes.

\section{F1 Grid column area}

In WRF, one of the following four projections can be used: the Lambert conformal, polar stereographic, Mercator, and latitude-longitude projections. These projections are implemented using map factors. In the computational space, the grid lengths $\Delta x(\mathrm{~m})$ and $\Delta y(\mathrm{~m})(\mathrm{d} x$ and $\mathrm{d} y$ variables in namelist.input) in $x$ and $y$ directions are constants. In the physical space, distances between grid points vary with position on the grid. Map factors $m x_{i, j}$ and $m y_{i, j}$ for both the $x$ and $y$ components are used for the transformation from computational to physical space and computed by geogrid.exe during the preprocessing stage. $m x_{i, j}$ and $m y_{i, j}$ are defined as the ratio of the distance in computational space to the corresponding distance on the Earth's surface (Skamarock et al., 2008):

$\left(m x_{i, j}, m y_{i, j}\right)=(\Delta x, \Delta y) /\left(\right.$ distance on the $\left.\operatorname{Earth}_{i, j}\right)$.

Map factors $m x_{i, j}$ and $m y_{i, j}$ for each $(i, j)$ vertical column are stored in wrfinput_d01 file in variables MAPFAC_MX and MAPFAC_MY, respectively. Thus, the area of $(i, j)$ column $S_{i, j}\left(\mathrm{~m}^{2}\right)$ in physical space is calculated using the following formula:

$S_{i, j}=\left(\Delta x / m x_{i, j}\right) \cdot\left(\Delta y / m y_{i, j}\right)$.

\section{F2 Dust emission}

For demonstration purposes, we use the original GOCARTWRF dust emission scheme (dust_opt=1) implemented in subroutine gocart_dust_driver() file module_gocart_dust.F. In this scheme, instantaneous dust emission flux $\left(\mathrm{kg} \mathrm{s}^{-1}\right.$ cell), calculated for each dust, bin is stored in the variables EDUST1,2,3,4,5. Other dust emission schemes (dust_opt=2,3) store instantaneous dust emission flux expressed in $\mathrm{g} \mathrm{m}^{-2} \mathrm{~s}^{-1}$ and $\mu \mathrm{g} \mathrm{m}^{-2} \mathrm{~s}^{-1}$, respectively. Thus, multiplying this flux by $\Delta t$ on each time step and by adding the value obtained to the previous value, we accumulate dust emission (kilograms per cell) from each surface grid cell. Thus, emission of dust from the first dust bin Emitted dust ${ }_{1}$ $(\mathrm{kg})$ is calculated using the following formula:

Emitted dust $_{1}=\sum_{i, j}\left(S_{i, j} / \Delta x \cdot \Delta y\right) \cdot \operatorname{EDUST}_{i, j}$,

where $S_{i, j}$ is the area of the $(i, j)$ column $\left(\mathrm{m}^{2}\right)$; see Eq. (F2). Here, we divide $S_{i, j}$ by $\Delta x \cdot \Delta y$ to account for the fact that in the subroutine gocart_dust_driver() dust emission are calculated in the computational space where grid cells have dimensions $\Delta x$ and $\Delta y$.

\section{F3 Gravitational settling and dry deposition}

The subroutines settling() implemented in module_gocart_settling.F and gocart_drydep_driver() implemented in module_gocart_drydep.F are used to calculate gravitational settling and dry deposition of dust. By default, instantaneous gravitational and dry deposition fluxes $\left(\mu \mathrm{g} \mathrm{m}^{-2} \mathrm{~s}^{-1}\right)$ are stored in variables GRASET_1,2,3,4,5 and DRYDEP_1,2,3,4,5, respectively. Thus, multiplying these 
fluxes on each time step by the time step $\Delta t$ and the scaling coefficient $10^{-9}$, and by adding the resulting value to the previous value, we obtain accumulated gravitational and dry deposition mass per unit area expressed in $\left(\mathrm{kg} \mathrm{m}^{-2}\right)$.

Hence, deposition of the dust from the first dust bin due to gravitational settling (Grav. settled dust $1, \mathrm{~kg}$ ) and dry deposition (Dry deposited dust $1, \mathrm{~kg}$ ) is calculated using the following formulas:

Grav. settled dust $1=\sum_{i, j} S_{i, j} \cdot$ GRASET_ $1_{i, j}$,

Dry deposited dust $1=\sum_{i, j} S_{i, j} \cdot$ DRYDEP_ $1_{i, j}$,

where $S_{i, j}$ is the area of the $(i, j)$ column $\left(\mathrm{m}^{2}\right)$; see Eq. (F2).

\section{F4 Dust in the atmosphere}

There are two approaches to calculate the amount of dust in the atmosphere (Dust in the atmosphere, $\mathrm{kg}$ ). In the first approach, we use dust column loadings (variables DUST$L O A D_{-} 1,2,3,4,5, \mu \mathrm{g} \mathrm{m}^{-2}$ ). Thus, the mass of dust in the first dust bin is given:
Dust in the atmosphere ${ }_{1}=10^{-9} \cdot \sum_{i, j} S_{i, j}$

$$
\text { ·DUSTLOAD_ } 1_{i, j},
$$

where $S_{i, j}$ is the area of the $(i, j)$ column $\left(\mathrm{m}^{2}\right)$; see Eq. (F2). In the second approach, we calculate the mass of air in each grid cell, multiply it by the dust mass mixing ratio (for example, $\mathrm{DUST}_{1}, \mathrm{\mu g} \mathrm{kg}^{-1}$ ) and sum over all grid cells in the domain:

Dust in the atmosphere ${ }_{1}=10^{-9} \cdot \sum_{i, j} S_{i, j}$

$$
\cdot \sum_{k} \operatorname{DUST}_{1 i, j, k} \cdot \Delta z_{i, j, k} \cdot 1 / \operatorname{ALT}_{i, j, k},
$$

where $\Delta z_{i, j, k}$ is the depth (m) (see Eq. C2) and $\mathrm{ALT}_{i, j, k}$ is the inverse dry air density $\left(\mathrm{m}^{3} \mathrm{~kg}^{-1}\right)$ in the grid cell $(i, j, k)$.

Gaseous concentrations expressed in ppmv need to be converted into mass mixing ratios ( $\mu \mathrm{g} \mathrm{kg}^{-1}$ ); see Eq. (D2). 
Code and data availability. The standard version of WRF-Chem is publicly available online at https://github.com/wrf-model/WRF (Skamarock et al., 2008). The Merra2BC interpolator is available online at https://doi.org/10.5281/zenodo.3695911 (Ukhov and Stenchikov, 2020).

Author contributions. AU planned and performed the calculations, wrote the manuscript, and led the discussion. RA, GG, and GS participated in the discussion and reviewed the manuscript.

Competing interests. The authors declare that they have no conflict of interest.

Acknowledgements. In this work, we used AERONET data from the KAUST Campus site that was maintained by Illia Shevchenko with the help of the NASA Goddard Space Flight Center AERONET team. We thank Brent Holben and Alexander Smirnov for the monitoring and regular calibrations of our instruments. We also used data from the Sede Boker and Mezaira sites and would like to thank their principal investigators (Arnon Karnieli and Brent Holben).

For computer time, this research used the resources of the Supercomputing Laboratory at KAUST.

The authors also would like to thank the three anonymous reviewers for their helpful comments.

Financial support. This research has been supported by the King Abdullah University of Science and Technology (KAUST, grant no. URF/1/2180-01-01).

Review statement. This paper was edited by Samuel Remy and reviewed by three anonymous referees.

\section{References}

Alghamdi, M. A., Almazroui, M., Shamy, M., Redal, M. A., Alkhalaf, A. K., Hussein, M. A., and Khoder, M. I.: Characterization and elemental composition of atmospheric aerosol loads during springtime dust storm in western Saudi Arabia, Aerosol Air Qual. Res., 15, 440-453, 2015.

Anisimov, A., Tao, W., Stenchikov, G., Kalenderski, S., Prakash, P. J., Yang, Z.-L., and Shi, M.: Quantifying local-scale dust emission from the Arabian Red Sea coastal plain, Atmos. Chem. Phys., 17, 993-1015, https://doi.org/10.5194/acp-17-993-2017, 2017.

Bagnold, R.: The physics of blown sand and desert dunes, William Morrow \& Company N.D., New York, USA, 1941.

Bangalath, H. K. and Stenchikov, G.: Role of dust direct radiative effect on the tropical rain belt over Middle East and North Africa: A high-resolution AGCM study, J. Geophys. Res.-Atmos., 120, 4564-4584, https://doi.org/10.1002/2015JD023122, 2015.
Banks, J. R., Brindley, H. E., Stenchikov, G., and Schepanski, K.: Satellite retrievals of dust aerosol over the Red Sea and the Persian Gulf (2005-2015), Atmos. Chem. Phys., 17, 3987-4003, https://doi.org/10.5194/acp-17-3987-2017, 2017.

Barnard, J. C., Fast, J. D., Paredes-Miranda, G., Arnott, W. P., and Laskin, A.: Technical Note: Evaluation of the WRF-Chem "Aerosol Chemical to Aerosol Optical Properties" Module using data from the MILAGRO campaign, Atmos. Chem. Phys., 10, 7325-7340, https://doi.org/10.5194/acp-10-7325-2010, 2010.

Belly, P.: Sand movement by wind, Tech. Mem. 1, US Army Coastal Eng. Res. Cent., Washington, D.C., USA, 1964.

Bian, H., Tie, X., Cao, J., Ying, Z., Han, S., and Xue, Y.: Analysis of a severe dust storm event over China: application of the WRFdust model, Aerosol Air Qual. Res., 11, 419-428, 2011.

Bosilovich, M., Lucchesi, R., and Suarez, M.: MERRA-2: File specification GMAO Office Note No. 9 (Version 1.1), available at: https://gmao.gsfc.nasa.gov/pubs/docs/Bosilovich785.pdf (last access: 20 January 2021), 2016.

Bukowski, J. and van den Heever, S. C.: Convective distribution of dust over the Arabian Peninsula: the impact of model resolution, Atmos. Chem. Phys., 20, 2967-2986, https://doi.org/10.5194/acp-20-2967-2020, 2020.

Chen, S., Zhao, C., Qian, Y., Leung, L. R., Huang, J., Huang, Z., Bi, J., Zhang, W., Shi, J., Yang, L., Li, D., and Li, J.: Regional modeling of dust mass balance and radiative forcing over East Asia using WRF-Chem, Aeolian Res., 15, 15-30, 2014.

Chen, S., Yuan, T., Zhang, X., Zhang, G., Feng, T., Zhao, D., Zang, Z., Liao, S., Ma, X., Jiang, N., Zhang, J., Yang, F., and Lu, H.: Dust modeling over East Asia during the summer of 2010 using the WRF-Chem model, J. Quant. Spectrosc. Ra., 213, 1-12, 2018.

Chin, M., Ginoux, P., Kinne, S., Torres, O., Holben, B. N., Duncan, B. N., Martin, R. V., Logan, J. A., Higurashi, A., and Nakajima, T.: Tropospheric aerosol optical thickness from the GOCART model and comparisons with satellite and Sun photometer measurements, J. Atmos. Sci., 59, 461-483, 2002.

Dee, D. P., Uppala, S., Simmons, A., Berrisford, P., Poli, P., Kobayashi, S., Andrae, U., Balmaseda, M., Balsamo, G., Bauer, D. P., Bechtold, P., Beljaars, A. C. M., Van de Berg, L., Bidlot, J., Bormann, N., Delsol, C., Dragani, R., Fuentes, M., Geer, A. J., Haimberger, L., Healy, S. B., Hersbach, H., Hólm, E. V., Isaksen, L., Kållberg, P., Köhler, M., Matricardi, M., McNally, A. P., Monge-Sanz, B. M., Morcrette, J.-J., Park, B.-K., Peubey, C., de Rosnay, P., Tavolato, C., Thépaut, J.-N., and Vitart, F.: The ERA-Interim reanalysis: Configuration and performance of the data assimilation system, Q. J. Roy. Meteor. Soc., 137, 553-597, 2011.

Dipu, S., Prabha, T. V., Pandithurai, G., Dudhia, J., Pfister, G., Rajesh, K., and Goswami, B.: Impact of elevated aerosol layer on the cloud macrophysical properties prior to monsoon onset, Atmos. Environ., 70, 454-467, 2013.

Dubovik, O. and King, M. D.: A flexible inversion algorithm for retrieval of aerosol optical properties from Sun and sky radiance measurements, J. Geophys. Res.-Atmos., 105, 20673-20696, 2000.

Eltahan, M., Shokr, M., and Sherif, A. O.: Simulation of severe dust events over Egypt using tuned dust schemes in weather research forecast (WRF-Chem), Atmosphere, 9, 246, https://doi.org/10.3390/atmos9070246, 2018. 
Emmons, L. K., Walters, S., Hess, P. G., Lamarque, J.-F., Pfister, G. G., Fillmore, D., Granier, C., Guenther, A., Kinnison, D., Laepple, T., Orlando, J., Tie, X., Tyndall, G., Wiedinmyer, C., Baughcum, S. L., and Kloster, S.: Description and evaluation of the Model for Ozone and Related chemical Tracers, version 4 (MOZART-4), Geosci. Model Dev., 3, 43-67, https://doi.org/10.5194/gmd-3-43-2010, 2010.

Farahat, A.: Air pollution in the Arabian Peninsula (Saudi Arabia, the United Arab Emirates, Kuwait, Qatar, Bahrain, and Oman): causes, effects, and aerosol categorization, Arab. J. Geosci., 9, 196, https://doi.org/10.1007/s12517-015-2203-y, 2016.

Fast, J., Gustafson Jr, W., Easter, R., Zaveri, R., Barnard, J., Chapman, E., Grell, G., and Peckham, S.: Evolution of ozone, particulates, and aerosol direct forcing in an urban area using a new fully-coupled meteorology, chemistry, and aerosol model, J. Geophys. Res, 111, D21305, https://doi.org/10.1029/2005JD006721, 2006.

Fast, J., Aiken, A. C., Allan, J., Alexander, L., Campos, T., Canagaratna, M. R., Chapman, E., DeCarlo, P. F., de Foy, B., Gaffney, J., de Gouw, J., Doran, J. C., Emmons, L., Hodzic, A., Herndon, S. C., Huey, G., Jayne, J. T., Jimenez, J. L., Kleinman, L., Kuster, W., Marley, N., Russell, L., Ochoa, C., Onasch, T. B., Pekour, M., Song, C., Ulbrich, I. M., Warneke, C., Welsh-Bon, D., Wiedinmyer, C., Worsnop, D. R., Yu, X.-Y., and Zaveri, R.: Evaluating simulated primary anthropogenic and biomass burning organic aerosols during MILAGRO: implications for assessing treatments of secondary organic aerosols, Atmos. Chem. Phys., 9, 6191-6215, https://doi.org/10.5194/acp-9-6191-2009, 2009.

Flaounas, E., Kotroni, V., Lagouvardos, K., Klose, M., Flamant, C., and Giannaros, T. M.: Assessing atmospheric dust modelling performance of WRF-Chem over the semi-arid and arid regions around the Mediterranean, Atmos. Chem. Phys. Discuss. [preprint], https://doi.org/10.5194/acp-2016-307, 2016.

Flaounas, E., Kotroni, V., Lagouvardos, K., Klose, M., Flamant, C., and Giannaros, T. M.: Sensitivity of the WRF-Chem (V3.6.1) model to different dust emission parametrisation: assessment in the broader Mediterranean region, Geosci. Model Dev., 10, 2925-2945, https://doi.org/10.5194/gmd-10-2925-2017, 2017.

Forster, P., Ramaswamy, V., Artaxo, P., Berntsen, T., Betts, R., Fahey, D., Haywood, J., Lean, J., Lowe, D., Myhre, G., Nganga, J., Prinn, R., Raga, G., Schulz, M., and Van Dorland, R.: Climate change 2007: the physical science basis, Contribution of Working Group I to the Fourth Assessment Report of the Intergovernmental Panel on Climate Change, Cambridge University Press, Cambridge, UK and New York, NY, USA, p. 212, 2007.

Fountoukis, C., Ackermann, L., Ayoub, M. A., Gladich, I., Hoehn, R. D., and Skillern, A.: Impact of atmospheric dust emission schemes on dust production and concentration over the Arabian Peninsula, Modeling Earth Systems and Environment, 2, 115, https://doi.org/10.1007/s40808-016-0181-z, 2016.

Ghan, S. J. and Zaveri, R. A.: Parameterization of optical properties for hydrated internally mixed aerosol, J. Geophys. Res.-Atmos., 112, D10201, https://doi.org/10.1029/2006JD007927, 2007.

Gillette, D. A. and Passi, R.: Modeling dust emission caused by wind erosion, J. Geophys. Res.-Atmos., 93, 14233-14242, 1988.

Ginoux, P., Chin, M., Tegen, I., Prospero, J. M., Holben, B., Dubovik, O., and Lin, S.-J.: Sources and distributions of dust aerosols simulated with the GOCART model, J. Geophys. Res.Atmos., 106, 20255-20273, 2001.
Gong, S.: A parameterization of sea-salt aerosol source function for sub- and super-micron particles, Global Biogeochem. Cy., 17, 1097, https://doi.org/10.1029/2003GB002079, 2003.

Grell, G. A., Peckham, S. E., Schmitz, R., McKeen, S. A., Frost, G., Skamarock, W. C., and Eder, B.: Fully coupled "online" chemistry within the WRF model, Atmos. Environ., 39, 6957-6975, 2005.

Holben, B. N., Eck, T. F., Slutsker, I., Tanre, D., Buis, J., Setzer, A., Vermote, E., Reagan, J., Kaufman, Y., Nakajima, T., Lavenu, F., Jankowiak, I., and Smirnov, A.: AERONET - A federated instrument network and data archive for aerosol characterization, Remote Sens. Environ., 66, 1-16, 1998.

Huang, Q., Marsham, J. H., Parker, D. J., Tian, W., and Grams, C. M.: Simulations of the effects of surface heat flux anomalies on stratification, convective growth, and vertical transport within the Saharan boundary layer, J. Geophys. Res.-Atmos. 115, D05201, https://doi.org/10.1029/2009JD012689, 2010.

Jish Prakash, P., Stenchikov, G., Kalenderski, S., Osipov, S., and Bangalath, H.: The impact of dust storms on the Arabian Peninsula and the Red Sea, Atmos. Chem. Phys., 15, 199-222, https://doi.org/10.5194/acp-15-199-2015, 2015.

Kalenderski, S. and Stenchikov, G.: High-resolution regional modeling of summertime transport and impact of African dust over the Red Sea and Arabian Peninsula, J. Geophys. Res.-Atmos., 121, 6435-6458, 2016.

Kalenderski, S., Stenchikov, G., and Zhao, C.: Modeling a typical winter-time dust event over the Arabian Peninsula and the Red Sea, Atmos. Chem. Phys., 13, 1999-2014, https://doi.org/10.5194/acp-13-1999-2013, 2013.

Karagulian, F., Temimi, M., Ghebreyesus, D., Weston, M., Kondapalli, N. K., Valappil, V. K., Aldababesh, A., Lyapustin, A., Chaouch, N., Al Hammadi, F., and Abdooli, A.: Analysis of a severe dust storm and its impact on air quality conditions using WRF-Chem modeling, satellite imagery, and ground observations, Air Qual. Atmos. Hlth., 12, 1-18, 2019.

Khan, B., Stenchikov, G., Weinzierl, B., Kalenderski, S., and Osipov, S.: Dust plume formation in the free troposphere and aerosol size distribution during the Saharan Mineral Dust Experiment in North Africa, Tellus B, 67, 27170 , https://doi.org/10.3402/tellusb.v67.27170, 2015.

Kumar, R., Barth, M. C., Pfister, G. G., Naja, M., and Brasseur, G. P.: WRF-Chem simulations of a typical pre-monsoon dust storm in northern India: influences on aerosol optical properties and radiation budget, Atmos. Chem. Phys., 14, 2431-2446, https://doi.org/10.5194/acp-14-2431-2014, 2014.

LeGrand, S. L., Polashenski, C., Letcher, T. W., Creighton, G. A., Peckham, S. E., and Cetola, J. D.: The AFWA dust emission scheme for the GOCART aerosol model in WRF-Chem v3.8.1, Geosci. Model Dev., 12, 131-166, https://doi.org/10.5194/gmd12-131-2019, 2019.

Lihavainen, H., Alghamdi, M., Hyvärinen, A.-P., Hussein, T., Aaltonen, V., Abdelmaksoud, A., Al-Jeelani, H., Almazroui, M., Almehmadi, F., Al Zawad, F., Hakala, J., Khoder, M., Neitola, K., Petäjä, T., Shabbaj, I. I., and Hämeric, K.: Aerosols physical properties at Hada Al Sham, western Saudi Arabia, Atmos. Environ., 135, 109-117, 2016.

Liu, S., McKeen, S., Hsie, E.-Y., Lin, X., Kelly, K., Bradshaw, J., Sandholm, S., Browell, E., Gregory, G., Sachse, G., Bandy, A., Thornton, D., Blake, D., Rowland, F., Newell, R., Heikes, B., 
Singh, H., and Talbot, R.: Model study of tropospheric trace species distributions during PEM-West A, J. Geophys. Res.Atmos., 101, 2073-2085, 1996.

Ma, S., Zhang, X., Gao, C., Tong, D. Q., Xiu, A., Wu, G., Cao, X., Huang, L., Zhao, H., Zhang, S., Ibarra-Espinosa, S., Wang, X., Li, X., and Dan, M.: Multimodel simulations of a springtime dust storm over northeastern China: implications of an evaluation of four commonly used air quality models (CMAQ v5.2.1, CAMx v6.50, CHIMERE v2017r4, and WRF-Chem v3.9.1), Geosci. Model Dev., 12, 4603-4625, https://doi.org/10.5194/gmd-124603-2019, 2019.

Marticorena, B. and Bergametti, G.: Modeling the atmospheric dust cycle: 1. Design of a soil-derived dust emission scheme, J. Geophys. Res.-Atmos., 100, 16415-16430, 1995.

Miller, R. and Tegen, I.: Climate response to soil dust aerosols, J. Climate, 11, 3247-3267, 1998.

Nabavi, S. O., Haimberger, L., and Samimi, C.: Sensitivity of WRFchem predictions to dust source function specification in West Asia, Aeolian Res., 24, 115-131, 2017.

Nguyen, H. D., Riley, M., Leys, J., and Salter, D.: Dust storm event of February 2019 in Central and East Coast of Australia and evidence of long-range transport to New Zealand and Antarctica, Atmosphere, 10, 653, https://doi.org/10.3390/atmos10110653, 2019.

O'Neill, N., Eck, T., Smirnov, A., Holben, B., and Thulasiraman, S.: Spectral discrimination of coarse and fine mode optical depth, J. Geophys. Res.-Atmos., 108, 4559, https://doi.org/10.1029/2002JD002975, 2003.

Osipov, S. and Stenchikov, G.: Simulating the regional impact of dust on the Middle East climate and the Red Sea, J. Geophys. Res.-Oceans, 123, 1032-1047, 2018.

Osipov, S., Stenchikov, G., Brindley, H., and Banks, J.: Diurnal cycle of the dust instantaneous direct radiative forcing over the Arabian Peninsula, Atmos. Chem. Phys., 15, 9537-9553, https://doi.org/10.5194/acp-15-9537-2015, 2015.

Parajuli, S. P., Stenchikov, G. L., Ukhov, A., and Kim, H.: Dust emission modeling using a new high-resolution dust source function in WRF-Chem with implications for air quality, J. Geophys. Res.-Atmos., 124, 10109-10133, 2019.

Parajuli, S. P., Stenchikov, G. L., Ukhov, A., Shevchenko, I., Dubovik, O., and Lopatin, A.: Aerosol vertical distribution and interactions with land/sea breezes over the eastern coast of the Red Sea from lidar data and high-resolution WRFChem simulations, Atmos. Chem. Phys., 20, 16089-16116, https://doi.org/10.5194/acp-20-16089-2020, 2020.

Powers, J. G., Klemp, J. B., Skamarock, W. C., Davis, C. A., Dudhia, J., Gill, D. O., Coen, J. L., Gochis, D. J., Ahmadov, R., Peckham, S. E., Grell, G. A., Michalakes, J., Trahan, S., Benjamin, S. G., Alexander, C. R., Dimego, G. J., Wang, W., Schwartz, C. S., Romine, G. S., Liu, Z., Snyder, C., Chen, F., Barlage, M. J., Yu, W., and Duda, M. G.: The weather research and forecasting model: Overview, system efforts, and future directions, B. Am. Meteorol. Soc., 98, 1717-1737, 2017.

Randles, C., da Silva, A. M., Buchard, V., Colarco, P., Darmenov, A., Govindaraju, R., Smirnov, A., Holben, B., Ferrare, R., Hair, J., et al.: The MERRA-2 aerosol reanalysis, 1980 onward. Part I: System description and data assimilation evaluation, J. Climate, 30, 6823-6850, 2017.
Rizza, U., Barnaba, F., Miglietta, M. M., Mangia, C., Di Liberto, L., Dionisi, D., Costabile, F., Grasso, F., and Gobbi, G. P.: WRF-Chem model simulations of a dust outbreak over the central Mediterranean and comparison with multi-sensor desert dust observations, Atmos. Chem. Phys., 17, 93-115, https://doi.org/10.5194/acp-17-93-2017, 2017.

Rizza, U., Miglietta, M. M., Mangia, C., Ielpo, P., Morichetti, M., Iachini, C., Virgili, S., and Passerini, G.: Sensitivity of WRFChem model to land surface schemes: Assessment in a severe dust outbreak episode in the Central Mediterranean (Apulia Region), Atmos. Res., 201, 168-180, 2018.

Shao, Y.: A model for mineral dust emission, J. Geophys. Res.Atmos., 106, 20239-20254, 2001.

Shao, Y.: Simplification of a dust emission scheme and comparison with data, J. Geophys. Res.-Atmos., 109, D10202, https://doi.org/10.1029/2003JD004372, 2004.

Shao, Y., Ishizuka, M., Mikami, M., and Leys, J.: Parameterization of size-resolved dust emission and validation with measurements, J. Geophys. Res.-Atmos., 116, D08203, https://doi.org/10.1029/2010JD014527, 2011.

Skamarock, W. C., Klemp, J. B., Dudhia, J., Gill, D. O., Barker, D. M., Wang, W., and Powers, J. G.: A description of the advanced research WRF version 2, Tech. rep., National Center For Atmospheric Research Boulder Co Mesoscale and Microscale Meteorology Div, Boulder, CO, USA, 2005.

Skamarock, W. C., Klemp, J. B., Dudhia, J., Gill, D. O., Barker, D., Duda, M., Huang, X. Y., Wang, W., and Powers, J. G.: A description of the Advanced Research (WRF) model, Version 3, Natl. Ctr. Atmos. Res., Boulder, CO, USA, available at: https://github.com/wrf-model/WRF (last access: 20 January 2021), 2008.

Su, L. and Fung, J. C.: Sensitivities of WRF-Chem to dust emission schemes and land surface properties in simulating dust cycles during springtime over East Asia, J. Geophys. Res.-Atmos., 120, $11-215,2015$.

Sulaiman, S. A., Singh, A. K., Mokhtar, M. M. M., and Bou-Rabee, M. A.: Influence of Dirt Accumulation on Performance of PV Panels, Energ. Proc., 50, 50-56, https://doi.org/10.1016/j.egypro.2014.06.006, 2014.

Ukhov, A. and Stenchikov, G.: Merra2BC. Interpolation utility for boundary and initial conditions used in WRF-Chem, Zenodo, https://doi.org/10.5281/zenodo.3695911, 2020.

Ukhov, A., Mostamandi, S., da Silva, A., Flemming, J., Alshehri, Y., Shevchenko, I., and Stenchikov, G.: Assessment of natural and anthropogenic aerosol air pollution in the Middle East using MERRA-2, CAMS data assimilation products, and high-resolution WRF-Chem model simulations, Atmos. Chem. Phys., 20, 9281-9310, https://doi.org/10.5194/acp-209281-2020, 2020a.

Ukhov, A., Mostamandi, S., Krotkov, N., Flemming, J., da Silva, A., Li, C., Fioletov, V., McLinden, C., Anisimov, A., Alshehri, Y. M., and Stenchikov, G.: Study of SO Pollution in the Middle East Using MERRA-2, CAMS Data Assimilation Products, and HighResolution WRF-Chem Simulations, J. Geophys. Res.-Atmos., 125, e2019JD031993, https://doi.org/10.1029/2019JD031993, 2020 b.

Wang, K., Zhang, Y., Yahya, K., Wu, S.-Y., and Grell, G.: Implementation and initial application of new chemistry-aerosol options in WRF/Chem for simulating secondary organic aerosols 
and aerosol indirect effects for regional air quality, Atmos. Environ., 115, 716-732, 2015.

Watson, A. J., Bakker, D., Ridgwell, A., Boyd, P., and Law, C.: Effect of iron supply on Southern Ocean $\mathrm{CO}_{2}$ uptake and implications for glacial atmospheric $\mathrm{CO}_{2}$, Nature, 407, 730-733, https://doi.org/10.1038/35037561, 2000.

Yuan, T., Chen, S., Huang, J., Zhang, X., Luo, Y., Ma, X., and Zhang, G.: Sensitivity of simulating a dust storm over Central Asia to different dust schemes using the WRF-Chem model, Atmos. Environ., 207, 16-29, 2019.

Zaveri, R. A., Easter, R. C., Fast, J. D., and Peters, L. K.: Model for simulating aerosol interactions and chemistry (MOSAIC), J. Geophys. Res.-Atmos., 113, D13204, https://doi.org/10.1029/2007JD008782, 2008.

Zhang, Y., Liu, Y., Kucera, P. A., Alharbi, B. H., Pan, L., and Ghulam, A.: Dust modeling over Saudi Arabia using WRF-Chem: March 2009 severe dust case, Atmos. Environ., 119, 118-130, 2015.

Zhao, C., Liu, X., Leung, L. R., Johnson, B., McFarlane, S. A., Gustafson Jr., W. I., Fast, J. D., and Easter, R.: The spatial distribution of mineral dust and its shortwave radiative forcing over North Africa: modeling sensitivities to dust emissions and aerosol size treatments, Atmos. Chem. Phys., 10, 8821-8838, https://doi.org/10.5194/acp-10-8821-2010, 2010.
Zhao, C., Liu, X., Ruby Leung, L., and Hagos, S.: Radiative impact of mineral dust on monsoon precipitation variability over West Africa, Atmos. Chem. Phys., 11, 1879-1893, https://doi.org/10.5194/acp-11-1879-2011, 2011.

Zhao, C., Liu, X., and Leung, L. R.: Impact of the Desert dust on the summer monsoon system over Southwestern North America, Atmos. Chem. Phys., 12, 3717-3731, https://doi.org/10.5194/acp12-3717-2012, 2012.

Zhao, C., Chen, S., Leung, L. R., Qian, Y., Kok, J. F., Zaveri, R. A., and Huang, J.: Uncertainty in modeling dust mass balance and radiative forcing from size parameterization, Atmos. Chem. Phys., 13, 10733-10753, https://doi.org/10.5194/acp-13-107332013, 2013.

Zhu, X., Prospero, J., and Millero, F. J.: Diel variability of soluble $\mathrm{Fe}$ (II) and soluble total $\mathrm{Fe}$ in North African dust in the trade winds at Barbados, J. Geophys. Res.-Atmos., 102, 21297-21305, 1997. 